\title{
Coastal Ecosystem Services, Social Equity, and Blue Growth: A Case Study from South-Eastern Bangladesh
}

\author{
Mohammad Mahmudul Islam ${ }^{1,2, * \mathbb{C}}$, Shuvo Pal ${ }^{1}$, Mohammad Mosarof Hossain ${ }^{1}$, \\ Mohammad Mojibul Hoque Mozumder ${ }^{3}(\mathbb{D})$ and Petra Schneider 4 (i) \\ 1 Department of Coastal and Marine Fisheries, Sylhet Agricultural University, Sylhet 3100, Bangladesh; \\ shuvo.rgmt@gmail.com (S.P.); mosarofmh.cmf@sau.ac.bd (M.M.H.) \\ 2 Department of Geography, Memorial University of Newfoundland, St. John's, NL A1B 3X9, Canada \\ 3 Helsinki Institute of Sustainability Science (HELSUS), Doctoral Programme in Interdisciplinary \\ Environmental Science (DENVI), Faculty of Biological and Environmental Sciences, University of Helsinki, \\ 00014 Helsinki, Finland; mohammad.mozumder@helsinki.fi \\ 4 Department for Water, Environment, Civil Engineering and Safety, University of Applied Sciences \\ Magdeburg-Stendal, D-39114 Magdeburg, Germany; petra.schneider@h2.de \\ * Correspondence: mahmud.cmf@sau.ac.bd
}

Received: 7 August 2020; Accepted: 15 October 2020; Published: 19 October 2020

\begin{abstract}
By employing empirical and secondary data (qualitative and quantitative), this study demonstrates how social equity (with its three dimensions) can meaningfully address the conservation of the coastal social-ecological system (SES), without losing diverse ecosystem services (ES) in south-east coastal Bangladesh. Based on this proposition, this study assesses the available ES and identifies the drivers responsible for ES changes, arguing for the application of social equity for resource conservation. The findings show that communities along Bangladesh's south-eastern coast use several ES for food, medicine, income, livelihoods, and cultural heritage. However, this valuable ecosystem is currently experiencing numerous threats and stressors of anthropogenic and natural origin. In particular, large-scale development activities, driven by the blue growth agenda, and neoliberalism policy, pose a risk to the local communities by degrading coastal ecosystem services. Escaping this situation for coastal natural resource-dependent communities in Bangladesh will require a transformation in the governance structure. Implementing the Small-Scale Fisheries (SSF) Guidelines that call for initiating policy change to deliver social justice to small-scale fisheries would help to address coastal ecosystem service conservation in Bangladesh.
\end{abstract}

Keywords: ecosystem service; small-scale fisheries; blue growth; social equity; the Bay of Bengal

\section{Introduction}

Ecosystem services are the conditions and processes through which natural ecosystems, and the species that form them, sustain and fulfill human life ([1], p. 2). Globally, coastal and marine natural resource systems are important for delivering various critical provisioning (e.g., food), cultural (e.g., a spiritual function), supporting (e.g., pollination), and regulatory (e.g., carbon sequestration) services for human well-being, mostly within one hundred kilometers of the coast [2,3]. As such, the ecosystem services (ES) concept has become an essential tool for connecting ecosystems to human well-being. To make decisions in a wide range of contexts, understanding this relationship is crucial [4]. Although the importance of coastal and marine ecosystem services is now well-established, these services and service-producing ecosystems are facing increasing pressures and threats, mostly due to human activities. For example, about $50 \%$ of salt marshes, $35 \%$ of mangroves, $29 \%$ of seagrasses, and $30 \%$ of coral reefs of the world have either been degraded or lost globally [5]. 
The cumulative and interconnected threats to coastal and marine ecosystems are increasing, while at the same time, the dependence on these goods and services is rising. Ignoring the role of ES in management decisions and policies may cause the continued destruction and degradation of coastal resources, such as mangroves [6,7]. Resource overexploitation and coastal degradation, coupled with inadequate environmental management, undermine the subsistence use of coastal ecosystems. However, rural and remote populations are not the only ones to suffer from the degradation; national economies are also affected [8]. There are concerns that poor communities may not reap any benefits from this new economic agenda; rather, they may need to further the disproportionate costs of any development projects in seascapes that spark debates on social equity and blue growth. As such, equity has become a crucial consideration in several global agendas. For example, the United Nations Agenda 2030 places equity at the heart of sustainable development. In the United Nations Sustainable Development Goals (SDGs), reducing inequalities is highlighted in 17 SDGs. It is recognized as the core concept for several other goals, to 'leave no-one behind' [9].

Globally, policymakers are often tasked with developing strategies, plans, and policies towards managing the environmental impacts and capitalizing the environmental opportunities associated with development and economic growth and development. Ecosystem Service Assessments and Valuations (ESAVs) can be employed as a tool to address this challenge. They can influence and shape community perceptions by communicating the core message of the importance of a functioning ecosystem to respective social groups and economic sectors. In addition, ESAVs can also provide much needed evidence on how society and the economy depend on a wide range of ecosystem services in terms of their survival, security, and growth. For example, these services are important for income, employment, food, shelter, energy, climate and disaster risk reduction, culture, material, and spiritual well-being [10]. For this, a functional classification that would allow meaningful comparisons across different projects, policy contexts, time, and space is essential. The Common International Classification of Ecosystem Services (CICES) is geographically and hierarchically consistent and can be applied to compare regions and integrate details of local studies into broader geographical understandings and decision-making [11].

Bangladesh has a $710 \mathrm{~km}$ long coastline and an Exclusive Economic Zone (EEZ) of 121,110 km². Bangladesh's marine system covers an estimated area of $118,813 \mathrm{~km}^{2}$, after resolving international verdicts on India and Myanmar's disputed maritime areas [12]. Ecosystem services from the marine and coastal resource systems play an important role in millions of coastal livelihoods in Bangladesh. In Bangladesh, coastal (estuarine and mangrove) and marine natural resource systems provide livelihood support and income to about 36 million inhabitants in Bangladesh's coastal zone. Many of them do not have other sources for food, revenue, and employment [13]. For instance, direct or indirect livelihood dependencies of approximately 270,000 fishing households on marine fishery along the Bangladesh coast have been noted [14]. Recently, Bangladesh's coastal zone became a hub of economic activities, thus becoming susceptible to over-exploitation, degradation, injustice, and marginalization.

Ocean-based resources may play critical roles in enhancing blue growth and achieving the UN Sustainable Development Goals (SDGs) prioritized by the Bangladesh government [12]. The Government of Bangladesh defines the Blue Economic concept as a sustainable pathway for the ocean economy [15]. According to the Seventh Five Year Plan, "Blue Economy comprises activities that directly or indirectly take place in the seas, oceans, and coasts using marine resources and eventually contributing to sustainable, inclusive economic growth, employment, well-being, while preserving the health of ocean" [16]. Bangladesh's approach to the Blue Economy also states that it "requires a balanced approach between conservation, development, and utilization of marine and coastal ecosystems, all aquatic resources and services" [17]. However, there are concerns that the nation-states attempting to fulfill the promises of blue growth and focus on the effective utilization of ocean-based resources to expedite economic growth and generate national wealth are likely to institute ocean governance systems that favor the highly capable economic actors (e.g., multinational corporations) and, in turn, prevent the small-scale economic actors from equally benefitting from the ocean-based 
economic development opportunities. There are concerns that management practices and governance strategies proposed in blue growth, which undervalue social objectives [18], lead to inequitable access to ocean-based development opportunities to generate private wealth, and contribute to undermining local people's rights or displacing them from their historical and traditional areas $[19,20]$. Understanding the value of ES to society is becoming increasingly vital for decision-and policymaking [21,22]. It can highlight the importance of the delicate coastal ecosystem for local and other communities' benefits in a broader context. The equitable distribution of costs and services should be a priority for any coastal development initiative, including blue growth initiatives.

It is worth mentioning that economic activities related to blue growth can negatively impact marine ecosystems. If these activities are not adequately regulated and managed, the capacities of marine ecosystems to provide the ES may be limited [23]. The complex nature of coastal social-ecological systems may cause vast uncertainty, which is fueled by lacking or limited knowledge of coastal and marine systems. Consequently, our understanding of current and future marine-terrestrial interactions, synergies, and trade-offs is being affected [24]. In Bangladesh, scientific research on the coastal and marine natural resource system is scarce, except for a few studies, e.g., those on coastal plantations [25], aquatic macrophytes [26], estuarine macrophytes [27], plant diversity [28], salt marshes, and seagrass [29]. Nevertheless, works on assessments, valuations, and coastal ecosystem services are emerging. However, studies addressing various ES and their categorization in the context of social justice and equity are remarkably absent. However, the framing of coastal ecosystem services in terms of social equity is gaining global importance, particularly in conjunction with the blue growth concept. With this backdrop, this study aims to investigate how social equity (with its three dimensions) can meaningfully address coastal social-ecological systems' conservation, without losing various ecosystem services from the seascape. The study systematically proceeded in the following way. First, it assessed the coastal ecosystem services along the south-eastern coast using the Common International Classification of Ecosystem Services (CICES). Secondly, it described the threats to these services, some of which are presently connected to, and may worsen in the future due to, blue growth initiatives. Finally, the article offers a critical analysis of the findings and a proposition on how addressing social equity can help the governance of coastal ecosystem services.

\section{Theoretical Framework}

Social equity represents an essential issue for ensuring equal treatment, evaluating what constitutes fair treatment in terms of both significant outcomes and ritual matters [30]. Additionally, equity requires that marginal groups favor affirmative governance actions [30]. Many conservation interventions have primarily approached equity in terms of the income distribution or benefits [31]. Social equity has three dimensions, which are as follows [30,31]:

- Recognitional equity implies the limit or facilitates people's access to the decision-making procedures, benefits, and resources;

- Procedural equity concerns an inclusive and active involvement of all stakeholders in decision-making and rule-making for conservation efforts;

- Distributional equity refers to the fairness of the distribution of benefits and liabilities of conservation measures among the various groups, including the present and future generations.

A critical environmental problem related to social equity is the inequitable use of ecosystem services (ESs), undermining ecosystems' sustainability and resilience [32]. Even though this concept is meant to describe the benefits that people may obtain from nature, it has emphasized that the poor's livelihoods and well-being excessively rely on access to ecosystem services [33]. The rural poor often depend on essential ecosystem services for their well-being and are potentially made vulnerable by their degradation or loss [32,34]. Indeed, threats to the poor's livelihoods are multifaceted and often evolve in a new context. Considering coastal and ocean space as a new economic frontier (i.e., blue growth) is also becoming a challenge for coastal communities. 
The blue growth concept is framed as the sustainable growth and development stemming from the economic activities in ocean and coastal zones and wetlands that minimize environmental degradation, biodiversity loss, and the untenable use of living aquatic resources, but maximize economic and social benefits [35]. In principle, blue growth aims to improve human well-being and social equity. Many development initiatives promoted by the blue growth agenda appear to ignore marginalized coastal communities (e.g., small-scale fisheries) by excluding them from discussions and policies. Therefore, disadvantaged coastal communities have become further marginalized [36]. It has become a challenge for policymakers to make coastal ecosystem services more inequitable to coastal people [37]. The case is particularly tricky, as in some contexts, blue growth is intended to maximize economic growth from the ocean frontier. Comparatively, for others, blue growth strives to maximize inclusive economic growth and prevent blue natural capital [37]. However, for sustaining the coastal ecosystem, it is vital to maintain social equity. For this, it is essential to appreciate and ensure the fair dealing of all stakeholders (receiving benefits or impacted by) with regards to existing ocean industries, including them in development policy and plans that would affect them [38,39]. However, there are concerns that the blue economy concept largely ignores social considerations (e.g., equitable access, sharing of the resources and benefits, and compliance of labor laws and human rights) [39]. Consequently, coastal resource-dependent communities, e.g., artisanal fishers, face the risk of the dispossession of resources [39]. For developing a more equitable and just space for coastal resource-dependent communities, it is important to understand the current situations on the ground to fully comprehend the kind of injustice and inequality they are experiencing [36]. In this context, the Small-Scale Fisheries (SSF) Guidelines, which were endorsed by the Food and Agriculture Organization of the United Nations (FAO), can be applied as an effective tool for ensuring equitable economic development considering both the social and ecological sustainability of coastal socio-ecological systems [39].

\section{Materials and Methods}

\subsection{Field Site Descriptions}

The study was conducted at four different study sites situated in two focal districts of Bangladesh's south-eastern coast, namely Chattagram and Cox's Bazar. Among the four areas, there were two sites (Salimpur and Kattali) from Chattagram district and two sites (Maheskhali and Sonadia Island) from Cox's Bazar district (Figure 1).
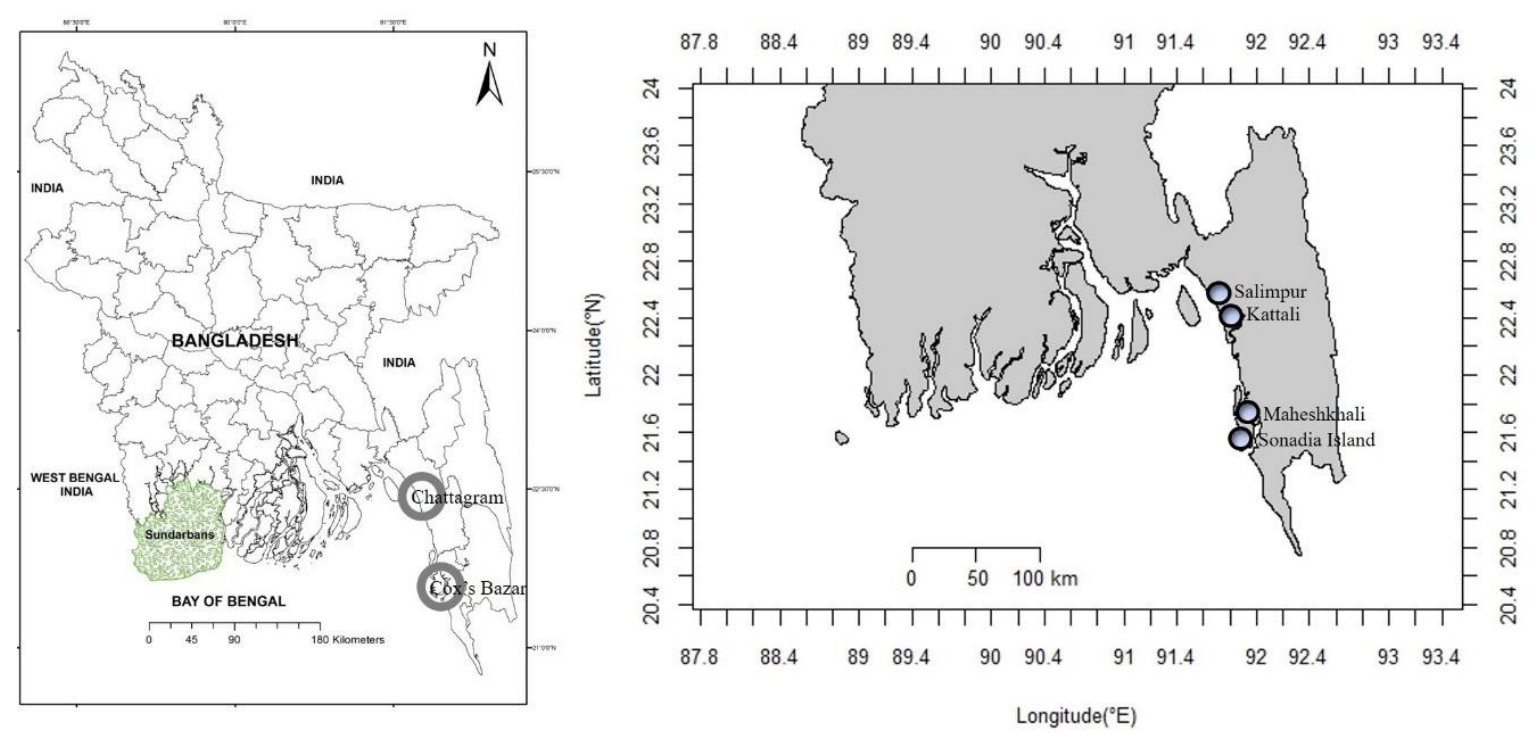

Figure 1. Location of the four study areas in Chattagram (Salimpur and Kattali) and Cox's Bazar (Maheskhali and Sonadia) districts along the Bangladesh coast. Modified from [40]. 
We divided our study areas into two distinct zones (two districts) along the south-eastern coast of Bangladesh next to the Bay of Bengal (BOB). Most artificial mangroves are situated along Bangladesh's central and south-eastern coastline. The Bangladesh coastal area supports approximately 530,000 ha of the mangrove ecosystem, of which 99,000 ha are artificial mangrove forest. The world's largest natural continuous block of mangrove ecosystem - the Sundarbans-lies in the south-west part of Bangladesh and covers nearly 6,000,000 ha [41,42]. The artificial mangrove areas planted by the Bangladesh Forest Department (FD), and most of the local rural communities, are dependent on coastal, intertidal, and marine natural resources for their income and livelihood. However, the difference in resource availability, level of dependency on the ecosystem services, access to resource extraction by the local community, socio-demographic situation, archaeological and touristic importance, coastal geomorphology and agroecological settings, conservation and management regimes, and magnitude of coastal development activities were the main criteria considered when selecting the study sites (Table 1). 
Table 1. Site features, comparative socio-demographic data, and spatial scenarios of study areas along the south-eastern coast of Bangladesh.

\begin{tabular}{|c|c|c|c|c|}
\hline \multirow{3}{*}{$\begin{array}{c}\text { Criteria } \\
\text { Study Area Coverage } \\
\begin{array}{c}\text { Study sites: site } \\
\text { (sub-district/Upazila) }\end{array}\end{array}$} & \multicolumn{4}{|c|}{ Site Characteristics } \\
\hline & \multicolumn{2}{|c|}{ Administrative District: Chattagram } & \multicolumn{2}{|c|}{ Administrative District: Cox's Bazar } \\
\hline & $\begin{array}{l}\text { Site1: Salimpur } \\
\text { (Sitakunda) }\end{array}$ & $\begin{array}{c}\text { Site 2: Kattali } \\
\text { (Chattagram Sadar) }\end{array}$ & $\begin{array}{l}\text { Site 1: Gorakghata } \\
\text { (Moheshkhali) }\end{array}$ & $\begin{array}{l}\text { Site 2: Sonadia Island } \\
\text { (Moheshkhali) }\end{array}$ \\
\hline $\begin{array}{l}\text { Distance from the district } \\
\text { headquarter }(\mathrm{km})\end{array}$ & $15-20$ & $5-7$ & $6-8$ & $8-10$ \\
\hline Area coverage $\left(\mathrm{km}^{2}\right)$ & $20.59 \mathrm{~km}^{2}$ & $3.73 \mathrm{~km}^{2}$ & $7.68 \mathrm{~km}^{2}$ & $13.0 \mathrm{~km}^{2}$ \\
\hline Population (number) & 45,237 & 115,134 & 35,000 & 38,380 \\
\hline $\begin{array}{l}\text { Coastal and marine natural } \\
\text { resources }\end{array}$ & $\begin{array}{l}\text { Planted mangrove forest } \\
\left(\text { ca. } 5 \mathrm{~km}^{2}\right) \text {, salt marsh habitat, } \\
\text { coastal space, } 2 \mathrm{~km} \text { long sea } \\
\text { beach with scenic beauty }\end{array}$ & $\begin{array}{l}\text { Planted mangrove forest } \\
\left(\text { ca. } 5 \mathrm{~km}^{2}\right) \text {, coastal space with } \\
\text { tourist attractions }\end{array}$ & $\begin{array}{l}\text { Planted mangrove forest, } \\
\text { salt marsh, coastal lagoons, } \\
\text { coastal space with scenic beauty }\end{array}$ & $\begin{array}{l}\text { Planted mangrove forest } \\
\text { (densely crescent shape), } \\
\text { coastal space, seabeach with } \\
\text { tourist attractions }\end{array}$ \\
\hline Frequency of patrolling & \multicolumn{2}{|c|}{$\begin{array}{l}\text { Frequent patrolling by authorized personnel of the } \\
\text { Forest Department }\end{array}$} & \multicolumn{2}{|c|}{$\begin{array}{c}\text { Frequent patrolling by authorized personnel of the Forest } \\
\text { Department and Coast Guard }\end{array}$} \\
\hline Main rivers, channels & \multicolumn{2}{|c|}{ Near to Bay of Bengal (BOB) } & \multicolumn{2}{|c|}{$\begin{array}{l}\text { Bakkali river, Maheshkhali channel linked with BoB by one of } \\
\text { its offshoots. }\end{array}$} \\
\hline Local geomorphology & \multicolumn{2}{|c|}{ Plainland } & \multicolumn{2}{|c|}{ Hilly and island } \\
\hline $\begin{array}{l}\text { Coastal development and } \\
\text { infrastructure }\end{array}$ & \multicolumn{2}{|c|}{$\begin{array}{l}\text { High magnitude. The new port link road is under construction } \\
\text { beside the beach. }\end{array}$} & \multicolumn{2}{|c|}{$\begin{array}{l}\text { High magnitude. Coal power plants, Liquid Natural Gas (LNG) } \\
\text { floating storage systems, LNG pipelines, unrefined fuel terminal, } \\
\text { deep seaport, etc. }\end{array}$} \\
\hline $\begin{array}{l}\text { Shrimp farming and land } \\
\text { encroachment }\end{array}$ & \multicolumn{2}{|c|}{ Shrimp is poly cultured with other freshwater species. } & \multicolumn{2}{|c|}{$\begin{array}{l}\text { Available to a higher degree with the conversion of forested land } \\
\text { into shrimp gher. }\end{array}$} \\
\hline Salt pan & \multicolumn{2}{|c|}{ No } & \multicolumn{2}{|c|}{ High and increasing since 2000} \\
\hline $\begin{array}{l}\text { Occupation among the } \\
\text { respondents }\end{array}$ & \multicolumn{2}{|c|}{$\begin{array}{l}\text { Multiple occupations, e.g., fishing, fish trading, cattle rearing, petty } \\
\text { business, service etc. }\end{array}$} & \multicolumn{2}{|c|}{$\begin{array}{l}\text { Mostly fishermen, e.g., fishing, marketing, shrimp farming, } \\
\text { mariculture, salt production, agriculture, forestry, day labor, small } \\
\text { business, and service. }\end{array}$} \\
\hline $\begin{array}{l}\text { Sources of alternative income } \\
\text { opportunity }\end{array}$ & \multicolumn{2}{|c|}{$\begin{array}{l}\text { More opportunities for alternative income sources as close to } \\
\text { urban areas. }\end{array}$} & \multicolumn{2}{|c|}{$\begin{array}{l}\text { Low level of income sources because of being isolated from } \\
\text { urban areas. }\end{array}$} \\
\hline $\begin{array}{l}\text { Proximity and communication } \\
\text { with sub-district and district }\end{array}$ & \multicolumn{2}{|c|}{$\begin{array}{l}\text { Comparatively closer to urban areas and communications are } \\
\text { available by road. }\end{array}$} & \multicolumn{2}{|c|}{$\begin{array}{l}\text { Communication system from Cox's Bazar city to island by local } \\
\text { motorboat or by speedboat, or by road from Chakaria (sub-district } \\
\text { of Cox's Bazar). }\end{array}$} \\
\hline
\end{tabular}




\subsection{Fieldwork and Data Collection}

Primary empirical data were collected from the study areas during nine (9) months of fieldwork, split into two sessions of July-December 2018 (6 months), and January-March 2019 (3 months). Primary data were collected by conducting 120 semi-structured questionnaire-based individual interviews (II), 4 focus group discussions (FGD), and 10 key informant interviews (KII) at the study sites (Table 2).

Table 2. Area coverage, site location, sample size, methods, and tools employed in the study.

\begin{tabular}{cccccc}
\hline \multirow{2}{*}{$\begin{array}{c}\text { Area Coverage } \\
\text { (District) }\end{array}$} & $\begin{array}{c}\text { Study Sites } \\
\text { (Sub-District) }\end{array}$ & $\begin{array}{c}\text { Geographical Position } \\
\text { System-GPS location }\end{array}$ & \multicolumn{3}{c}{$\begin{array}{c}\text { Methods and Sample Size } \\
\text { (Number) }\end{array}$} \\
\cline { 4 - 6 } Chattagram & $\begin{array}{c}\text { Salimpur } \\
\text { (Sitakunda) }\end{array}$ & $22^{\circ} 37^{\prime} \mathrm{N}, 91^{\circ} 397^{\prime} \mathrm{E}$ & 30 & 2 & 1 \\
\hline $\begin{array}{c}\text { Kattali } \\
\text { (Chattagram Sadar) }\end{array}$ & $22^{\circ} 21^{\prime} \mathrm{N}, 91^{\circ} 46^{\prime} \mathrm{E}$ & 30 & 2 & 1 \\
\hline Cox's Bazar & $\begin{array}{c}\text { Gorakghata } \\
\text { (Moheshkhali) }\end{array}$ & $21^{\circ} 31^{\prime} \mathrm{N}, 91^{\circ} 58^{\prime} \mathrm{E}$ & 30 & 4 & 1 \\
\hline & $\begin{array}{c}\text { Sonadia Island } \\
\text { (Moheshkhali) }\end{array}$ & $21^{\circ} 29^{\prime} \mathrm{N}, 91^{\circ} 53^{\prime} \mathrm{E}$ & 30 & 2 & 1 \\
\hline Total & & 120 & 10 & 4 \\
\hline
\end{tabular}

Participatory Rural Appraisal (PRA) tools, explicitly II and FGD primary resource users and KII with key resource people, were employed at the study sites (Table 3). Secondary data were collected during desk work by reviewing peer-reviewed literature. 
Table 3. Methodological tools within the Participatory Rural Appraisal (PRA) framework, nature of participants and focal logistical aspects, arrangement perspectives, and gathered information employed in the study.

\begin{tabular}{|c|c|c|c|c|}
\hline Methodological Tools & $\begin{array}{l}\text { Stakeholders-Nature of Participants } \\
\text { and Focal Logistical Aspects }\end{array}$ & $\begin{array}{c}\text { Arrangement } \\
\text { Perspectives/Settings }\end{array}$ & Time Frame and Location & Information Gathered/Output \\
\hline Individual Interview (II) & $\begin{array}{l}\text { Primary resource users-fishermen. } \\
\text { The information gathered included } \\
\text { topics of physical, social, natural, and } \\
\text { economical aspects. }\end{array}$ & $\begin{array}{l}\text { Face-to-face mode facilitated } \\
\text { with a semi-structured } \\
\text { questionnaire (Appendix A). }\end{array}$ & $\begin{array}{l}\text { Duration: } 60-90 \mathrm{~min} . \\
\text { Location: house/field/local } \\
\text { market, with pre-decided time } \\
\text { frame after personal } \\
\text { communication. }\end{array}$ & $\begin{array}{l}\text { Demographic status and socio-economic } \\
\text { condition of resource users. } \\
\text { Characterizing the uses of coastal and } \\
\text { marine resources. } \\
\text { Identifying the factors responsible for the } \\
\text { changes in ES. }\end{array}$ \\
\hline $\begin{array}{l}\text { Focus Group Discussion } \\
\text { (FGD) }\end{array}$ & $\begin{array}{l}\text { The discussion conducted with various } \\
\text { resource user stakeholder groups, e.g., } \\
\text { fishermen, petty business owners, tree } \\
\text { cutters, and honey collectors. }\end{array}$ & $\begin{array}{l}\text { Different stakeholders talk to } \\
\text { each other and generate new } \\
\text { knowledge. } \\
\text { Group size of } 5-10 \text { people. } \\
\text { The group discussion was } \\
\text { supported by the checklist. }\end{array}$ & $\begin{array}{l}\text { Duration: } 45-90 \text { min session. } \\
\text { Location: local market, free } \\
\text { space on the riverside, and } \\
\text { community space, pre-selected } \\
\text { time frame after personal } \\
\text { communication. }\end{array}$ & $\begin{array}{l}\text { Crosschecked with the collected } \\
\text { information and elicited the holistic } \\
\text { essence of resource uses and their } \\
\text { dynamics of local setting changes. }\end{array}$ \\
\hline $\begin{array}{l}\text { Key informant interview } \\
\qquad(\mathrm{KII})\end{array}$ & $\begin{array}{l}\text { The interview conducted amongst key } \\
\text { resource persons assumed to be } \\
\text { knowledgeable about the local } \\
\text { perspectives, including the resource } \\
\text { systems. }\end{array}$ & $\begin{array}{l}\text { Face-to-face oral consultation } \\
\text { with key persons that include } \\
\text { researchers, Government of } \\
\text { Bangladesh officials, local } \\
\text { resource managers, } \\
\text { Non-governmental organization } \\
\text { staff, school teachers, and local } \\
\text { leaders. }\end{array}$ & $\begin{array}{l}\text { Duration: } 30-60 \text { min time span } \\
\text { Location: places and time were } \\
\text { pre-scheduled based on } \\
\text { personal } \\
\text { consultation/appointments. }\end{array}$ & $\begin{array}{l}\text { Overview of the prevailing associated } \\
\text { aspects of the local context. } \\
\text { Validate the information gathered on } \\
\text { resource utilization, identifying the } \\
\text { linkages with ES, social equity, } \\
\text { blue growth perspectives, and } \\
\text { management regimes. }\end{array}$ \\
\hline
\end{tabular}




\subsection{Data Analysis}

Quantitative data were analyzed using Microsoft Excel. Qualitative data were analyzed through text analysis. After transcribing qualitative data, contents were analyzed, and themes were developed and classified into variables for providing further explanations.

\section{Results}

\subsection{Respondents' Profile}

Most of the study sites' respondents were from the age group of 30-39 years and experienced the issues discussed (Appendix A, Table A1). Many of the respondents were illiterate and depended on fisheries or other natural resource-dependent occupations, earning below 15,000 BDT (1 USD = 85.12 BDT). Many respondents depended on natural resources for more than $70 \%$ of their monthly income, and lived in tin-shaded houses, moderately resistant to extreme events (Appendix A, Table A1).

\subsection{Assessment of Ecosystem Services (ESs) in the Study Areas}

After analyzing the qualitative and quantitative empirical and secondary data, it could be observed that three types, i.e., provisioning, regulatory and maintenance, and cultural ES, are primarily derived from the Chattagram coast. Following the CICES framework, seven categories of provisioning services (Table 4) and three cultural services (Table 5) that benefited the coastal communities, either directly or indirectly, were recorded. Almost all respondents $(98.33 \%)$ considered coastal fisheries as an essential source of food. Slightly more than eighty percent considered the importance of the coastal ecosystem as a source of firewood. Aesthetic and recreation data formed another set of valuable ecosystem service mentioned by the respondents $(63.33 \%)$. The respondents also cited several other ecosystem services (Figure 2), including medicinal value $(31.67 \%)$, food from mangroves $(10 \%)$, fodder $(46.67 \%)$, timber (23.33\%), religious and rituals' importance (13.33\%), education and research value $(16.67 \%)$, and other uses of fisheries and mangroves $(6.67 \%)$.

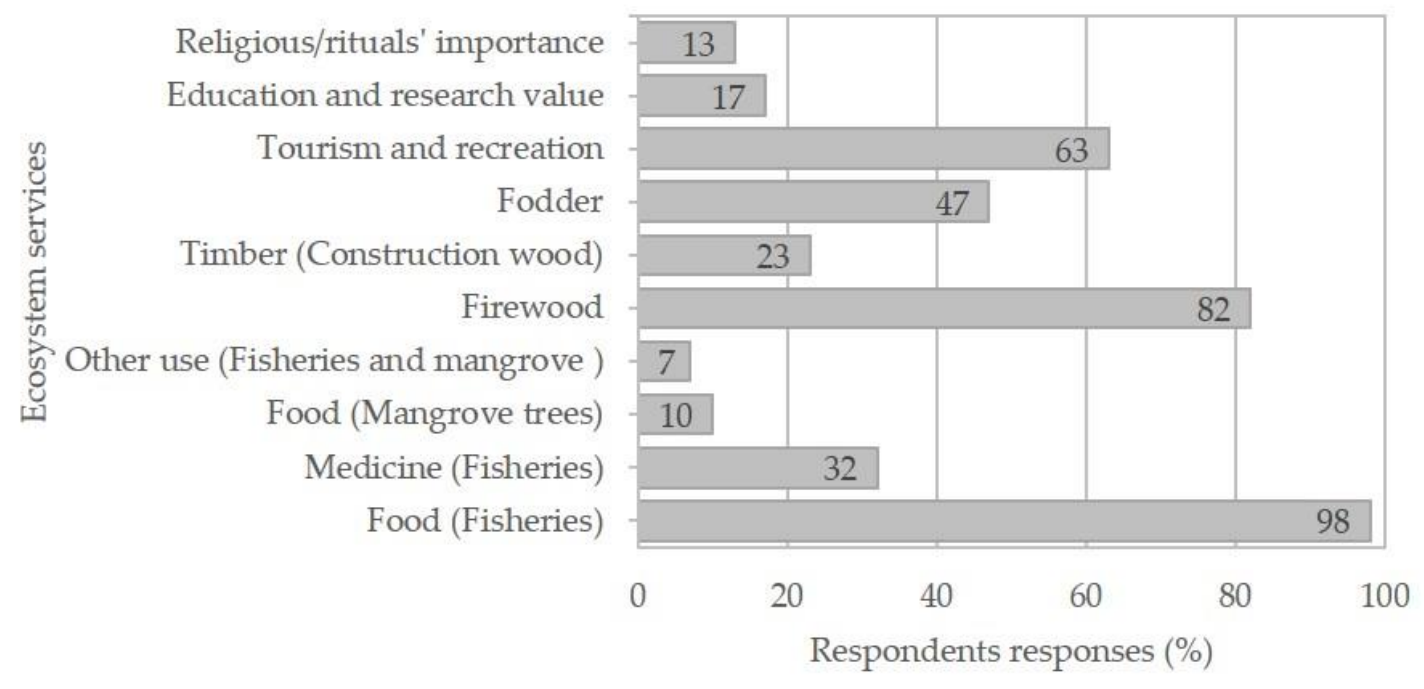

Figure 2. Ecosystem services derived from the coastal and mangrove ecosystems on the south-eastern coast of Bangladesh (respondents perceived to benefit from individual or community levels). 
Table 4. Provisioning ecosystem services from the south-eastern coast of Bangladesh.

\begin{tabular}{|c|c|}
\hline Ecosystem Services & Brief Description of Provisioning Services \\
\hline Foods (fisheries) & $\begin{array}{l}\text { - } \quad \text { Fish and shellfish, e.g., shrimp/prawns, are considered as dominant food. } \\
\text { - } \quad \text { Kry fish is produced commercially. } \\
\text { - } \quad \text { The fleshy part of Hooded oysters (Crassostrea cucullata Born) is used as food. } \\
\text { - } \quad \text { Fish, e.g., Hilsa (Tenualosa ilisha Hamilton) Indian river shad, Coral (Lates calcarifer Bloch) } \\
\text { Sea bass, Kala poa (Atrobucca nibe Jordan and Thompson) Black mouth croaker, Kamila } \\
\text { (Congresox talabonoides Bleeker) Indian pike conger, and Lakkha (Leptomelanosoma indicum } \\
\text { Shaw) Indian threadfin, has high commercial value. } \\
\text { - Hangar (Carcharhinus dussumieri (Müller and Henle)) Whitecheek shark, Perki (Loligo } \\
\text { forbesii Steenstrup) Inshore Squid, Octopus (Octopus vulgaris Lamarck), Lal poa (Pennahia } \\
\text { argentata Houttuyn) Silver croaker, etc., have a good demand as fishery by-products. }\end{array}$ \\
\hline
\end{tabular}

- $\quad$ Loitta (Harpadon nehereus Hamilton) Bombay duck, Kakra or Haobba (S. serrata) Mud crab, Perki (Loligo sp.) Squid, Lal kakra (Austruca annulipes H. Milne Edwards) Fiddler crab, Kain magur (Plotosus lineatus Tunberg) Striped eel catfish, Mur baila (Grammoplites scaber Linnaeus) Rough flat head, and Mur baila (Platycephalus indicus Linnaeus) Bartail

Medicine (fisheries) Flathead, have various kinds of medicinal value.

- $\quad$ People prefer Icha/Chingri (Peneaus sp.) shrimp/prawn, Kakra or Haobba (S. serrata) Mud crab, Haush, Sankush (Himantura uarnak Gmelin) Honeycomb stingray, Chewa (Boleopthalmus boddarti Pallas) Mud skipper, and Hilsa (Tenualosa ilisha Hamilton) Indian river shad because of their medicinal value.

- $\quad$ Fruits of Keora (Sonneratia apetala Buch.Ham.) Crab apple mangrove or mangrove apple is used as food.

Food (mangroves)

- The seeds of Culi-gach, Cilla-gula, Gila, Titgila (Entada rheedii Spreng) Dream herb, Snuff box sea bean, Liane Sabre, and Liana are like peanuts after boiling.

- The seed of a wild grass Urigash, Urigrass (Porteresia coarcata Roxb.), a relative of rice, is taken as puffed rice.

- $\quad$ Small-sized Gastropods, including Leza and Kansya (Telescopium telescopium Linnaeus) Snails are used as building material by mixing them with cement.

- Hard shell of Hooded oyster (C. cucullata) is used as lime after grinding.

Other use (fisheries and

- Larger sized snails are sold as an ingredient at the feed mill. mangroves)

- Lower valued fish species are used as bait in long lining.

- Cuchia (Monopterus cuchia Hamilton) Gangetic mud eel is only harvested for bait for mud crab harvesting.

- The seed of Sada Baen (Avicennia alba Blume) White mangroves (called Bai-gach locally) is used as bait for the fishhook.

Food (other sources)

- $\quad$ Migratory birds are captured illegally and taken as food.

Firewood/fuel wood

- Stems/trimmed parts/branches of various mangrove plants, such as S. apetala (Keora), Moricha Baen (Avicennia marina Forssk. Vierh) Gray Mangrove, Kala Baen (Avicennia officinalis L.) Indian mangrove, A. alba (Sada Baen), Nuniagach (Aegialitis rotundifolia Roxb.), and Nona jau (Tamarix gallica L.) Tamarisk, are used as fuelwood.

- $\quad$ Matured stems of A. officinalis (Kala Baen), A. alba (Sada Baen), A. marina (Moricha Baen), T. gallica (Nona jau), and A. rotundifolia (Nuniagach) are used as construction wood, e.g., for poles of Behundijal, tents, boats, huts, paddles of boats, bridge construction in small channels, fences, and bush traps.

- $\quad$ Leaves of A. alba (Sada Baen), A. officinalis (Kala Baen), A. marina (Moricha Baen), and S. apetala (Keora) are used for domestic animals.

Fodder

- $\quad$ Leaves of P. coarctata (Urigash, Urigrass) are used as fodder.

- The seashore area is used as grazing land. 
Table 5. Cultural ecosystem services (ES) and other services from the south-eastern coast of Bangladesh.

\begin{tabular}{|c|c|}
\hline Ecosystem Services & Brief Description of Cultural Services \\
\hline Ecotourism and recreation & $\begin{array}{l}\text { - The Kattali sea beach is famous for its sunset. } \\
\text { - Tourism, e.g., mangrove area is used as a tourist spot. Religious values: Visitors are attracted and visit various places } \\
\text { with historical and religious importance. } \\
\text { Maoeshkhali Island, the only hilly island in Bangladesh, attracts tourists because of its picturesque and quiet beaches, } \\
\text { majestic mangrove jungles, impressive ranges of stunning landscapes and mountains, peaceful and scenic beaches, the } \\
\text { temple of Adinath, the quaint Buddhist temple, and the pagoda of the local Rakhine tribe. } \\
\text { - Several parks have been set up near the Kattali beach to attract visitors. } \\
\text { - Visitors also visit various places of historical importance, e.g., Hindu devotees take a holy bath in the sea at the Rani } \\
\text { Rashmoni Ghat, known as Kattali beach, on 'Baruni Snan' during Madhu Krishna Tithi of Chaitra, the last month of the } \\
\text { Bangla calendar. } \\
\text { - 'Ganga-Puja', a festivity of the Hindu religion, is held in the beach area of Maoeshkhali. } \\
\text { Flower of Hargoza (Acanthus ilicifolius Linnaeus) Holly-leaved acanthus, Sea holly, or Holy mangrove is used in the } \\
\text { worship of 'Chaitra-Sankranti.' }\end{array}$ \\
\hline Educational and research value & $\begin{array}{l}\text { - For mangrove habitats, marine turtle breeding grounds (sea-turtle research on Sonadia Island), and bird surveying, } \\
\text { Moheshkhali and Sonadia Island have received researchers' attention. Education and research value, e.g., support } \\
\text { research and education as attractive natural venues, mostly for mangrove, sea-turtle, and bird surveying. }\end{array}$ \\
\hline Religious/ritual importance & $\begin{array}{l}\text { - In the Ramayana and Puranas scripts, a hill mentioned as Moinak Porbot was located near the fishing village, while } \\
\text { Ganga was cited as a mighty or holy river. } \\
\text { - The seed of the local 'Ghila' (Ipomoea pes-caprae L.) Beach morning glory is used in the festivities of 'Chaitra-Sankranti'. }\end{array}$ \\
\hline
\end{tabular}




\subsubsection{Provisioning Services}

The south-eastern coastal region of Bangladesh provides various kinds of provisioning services to the people living in the coastal zone. Based on respondents' narratives, and by employing the CICES framework, seven provisioning services that benefit the people directly, e.g., foods, fisheries, medicine, firewood, timber, and fodder, were recorded in the study areas (Table 4).

\section{Food (Fisheries)}

Based on the information provided by the respondents, as well as field observations and secondary literature, about 137 species of fishery taxa, including 115 species of fin-fish, 10 species of shark and ray (Chondrichthyes), 6 species of prawn and shrimp, and 6 species of crab, were recorded in the study areas (Appendix A, Table A2). The harvested catch is sold commercially at the local market, and a part of the catch is also used for subsistence. Traditional and modern fishing gear is used to catch a wide variety of fish species. Coastal and mangrove habitats also support aquaculture. Dry fish is the favorite food item among all kinds of religious people in the Chattagram region. Tribal communities, e.g., Rakhine, prefer to eat curry rich in Ngappi, which is a fermented paste made from small shrimp/prawn [41]. Mud crab (S. serrata) is a trendy food item that has a global market. Many people are engaged in crab collection from the mangroves adjacent to the shoreline during low tide. Some women in Moheshkhali collect Hooded oysters (C. cucullata) from the mangroves and nearby wetlands. These oysters are called 'Siloin' locally and are very popular among the Rakhine tribe and Hindu people. The fleshy and soft portion of these oysters is employed as food. The hard-outer shell is used for edible lime production after grinding (Table 4, Figure 3).

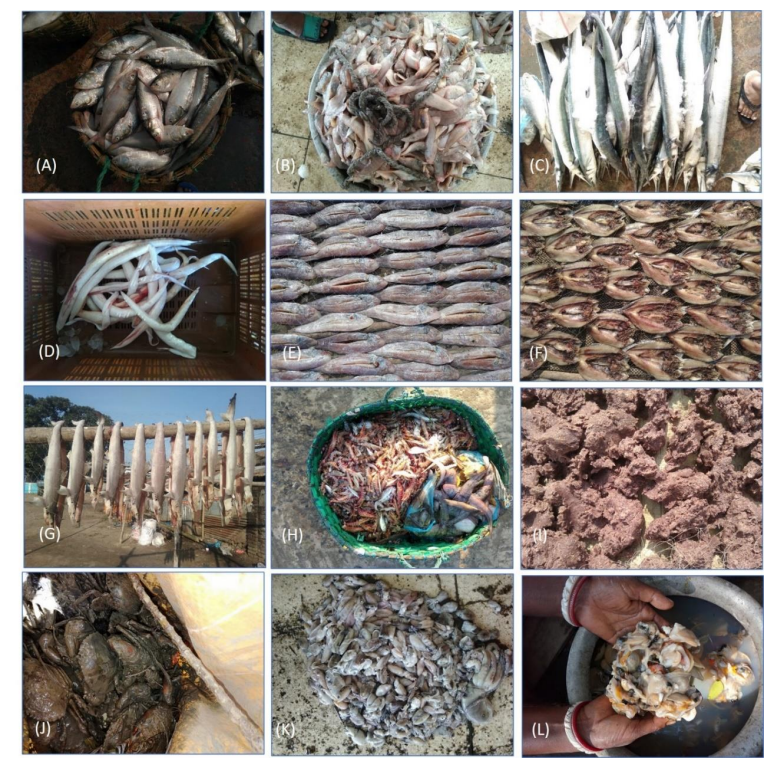

Figure 3. Fishery resources with multidimensional uses (provisioning services) in the studied south-eastern coastal areas of Bangladesh: (A) Hilsa shad species Tenualosa ilisha (Hamilton, 1822)_Ilish, the national fish of Bangladesh; (B) Bombay duck, Harpadon nehereus (Hamilton, 1822)_Loitta fish waiting for sale, usually used for raw and dried food items; (C) harvested Indian pike conger, Congresox talabonoides Bleeker-Kamila fish at the landing center, Moheskhali; (D) highly valued raw gas bladder of C. talabonoides; (E) fishery products: Sun drying of Kukurjib fish-Gangetic tongue sole, Cynoglossus cynoglossus (Hamilton, 1822); (F) sun drying of Rupchanda - Chinese silver pomfret, Pampus chinensis (Euphrasen, 1788); (G) sun drying of Thuttre hangar-Spadenose Shark, Scoliodon laticaudus (Müller \& Henle, 1838); (H) harvested catch—shrimp in the basket; (I) shrimp paste-Ngappi preparation in Moheshkhali; (J) Kakra/Haobba, mud crab, Scylla serrata (Forskal, 1775); (K) Cephalopods-Sepia, Loligo, Octopus often used as bait in long lining; (L) oyster used in food processing for food preparation (Photo credit: Shuvo Pal). 
Food (Mangrove Resources)

According to the Department of Forest (FD) local office, the planted mangrove forest comprises nine species in the study areas (Appendix A, Table A3). The respondents of the present study were aware of the fishery significance of the mangrove forest in their regions. Apart from 58 wildlife and 270 bird species, 201 fishery taxa, including 53 pelagic fish, 124 demersal fish, and 24 shrimp/prawn species, have been reported in Bangladesh's mangrove systems [43]. In both Chattagram and Moheshkhali, multiple uses of mangrove products as food have been reported (Table 4).

There is also non-food utilization of fisheries and mangroves. There is a good demand for fishery by-products in the international market, as revealed by FGD in Moheshkhali. The gas bladders of C. talabonoides, L. calcarifer, A. nibe, and L. indicum are used in plastic surgery and the making of clinical thread. The fin of G. gangeticusis is exported for making soup. The full part of the body of Loligo sp., $O$. vulgaris, and P. argentata also has a good demand. Among them, the gas bladder of Blackmouth croaker (A. nibe) and Indian threadfin (L. indicum) is in high demand, fetching high value in the export market. Thailand, China, and Vietnam are the buyer countries of these fishery by-products (Table 4).

Pharmaceuticals and Medicinal Uses—Fishery Items and Mangrove Plants

Fishermen use crustaceans, shellfish, and other marine species as traditional medicine for various health issues. Some of the most common uses include their employment as good protein sources containing a high amount of iodine, cough relief, appetizers, substances for preventing night-blindness, and substances for enhancing the eye's vision [44]. Bombay duck (H. nehereus) is preferred due to it being a good source of iron and iodine. Mud crab (S. serrata) and Loligo sp. are favored as energizers, appetizers, and good protein sources. A. annulipes is designed to alleviate children's tooses and colds. P. lineatus is taken to enhance the blood content in the body. G. scaber and P. indicus are taken for enhancing the milk content of a breastfeeding mother [41]. It was found that people prefer shrimp/prawn Peneaus sp. for pain reduction and appetizers; S. serrata for dysentery, muscular pain, and improving the vision of the eye; H. uarnak for muscular pain, amoebic dysentery, and enhancing the milk content of a breastfeeding mother; B. boddarti for skin burns and purifiers of blood; and Hilsa sp. to improve energy, relieve flatulence, and benefit heart functioning [41].

Mangrove plants are used for various medicinal purposes worldwide. Acanthus ilicifolius L. (Hargoza) is used to treat asthma and rheumatism. A. officinalis is a remedy for boils and tumors, and unripe seeds are placed as a poultice onto abscesses, boils, and smallpox sores. Excoecaria agallocha L. (Gewa) is used as a caustic for removing obstinate ulcers, and as an emetic and purgative for treating pneumonia or asthma. T. gallica treats liver disorders, rheumatic pain, diarrhea, dysentery, open cuts, sores, skin wounds, bleeding disorders, constipation, piles, and gastrointestinal issues. Several medicinal mangrove plants, their therapeutic qualities, and their uses are unknown to the local population.

\section{Firewood/Fuelwood}

Small stems, branches, and trunks, as well as whole plants, are used as firewood. During the fieldwork in Moheskhali and Sonadia Island, it was found that people collect the small branches and trunks which have fallen on the ground for use as fuel. Local people use them because they are easy to access and due to their sound quality, in addition to the fact that they produce a large amount of heat, without generating much smoke. Some collect them for domestic use and some for sale. The branches and stems are also stored for future use, mostly for the rainy season.

Timber

For construction purposes, mangrove plants are frequently used as fishing poles, pillars, poles for making houses, the fencing of homestead areas, houses, kitchens, animal sheds, etc. Small branches, trunks, and stems of mangrove plants are used as fencing materials and for service wood (e.g., timber for 
furniture, boat making, fishing devices, etc.). Mature and straight-shaped Avicenna sp. are collected illegally and used as fishing poles of estuarine set bag nets (Behundijal) at Salimpur. A. officinalis is used for bridge construction in the small canal flowing into the mangrove area. It is also used as poles or tents in Kattali. In Moheshkhali, people use A. alba and A. marina to construct poles in boats and paddles of boats. T. gallica is used for poles for wooden sluice gates and is also used for poles in hut construction in the shrimp farming or salt pan area. A. rotundifolia is used as fencing material in this area. It is also used as a bush trap, where people make embankments beside the mangrove area, locally known as 'Khati', to catch the fish which accompany the high tidewater (Table 4).

Fodder

Several species of plant materials are used as fodder in the study areas. In Salimpur, herding is the profession of some, who let their cattle graze in the forest area. In mangrove areas of the study areas, buffalo, cattle, goat, and other domestic animals can graze. Small leaves and stems are stored for the future. The mangrove area fulfills the fodder's demand to feed domestic animals almost all year round, except during the rainy season.

\subsubsection{Cultural Services}

According to the CICES framework, three cultural services that directly or indirectly benefited the coastal communities of the south-eastern coastal region of Bangladesh were recorded in the study areas (Table 5, Figure 4).
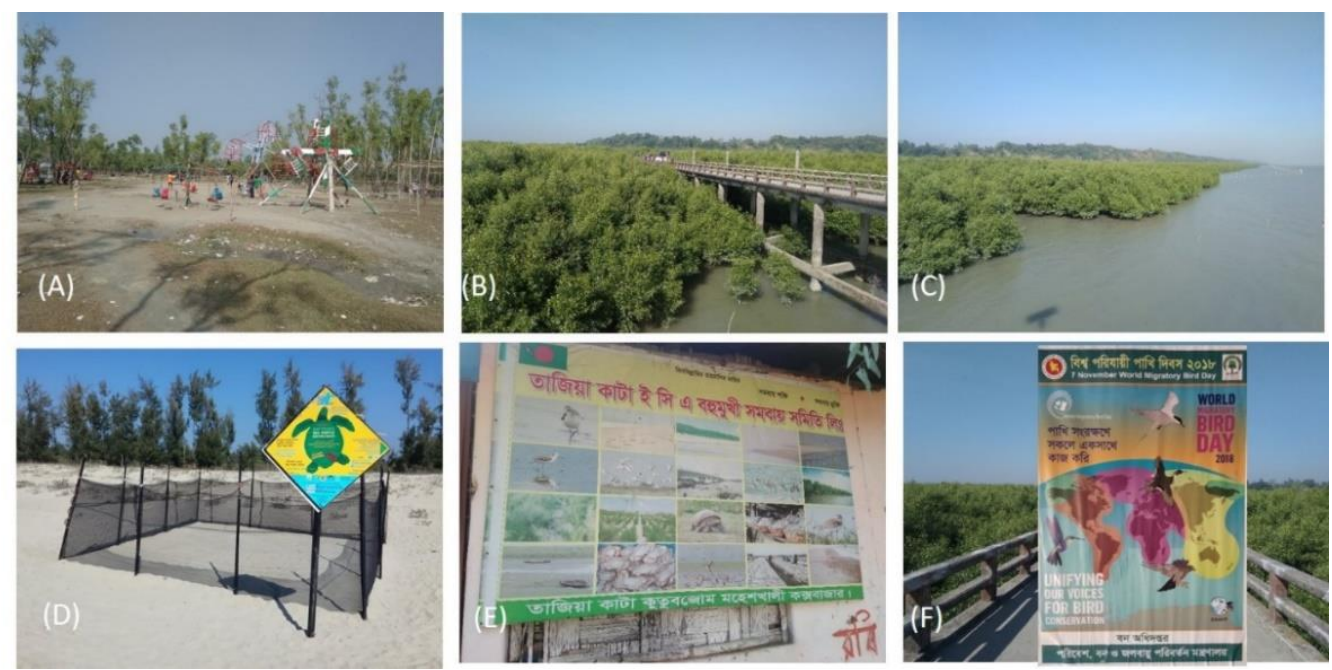

Figure 4. Cultural ecosystem services, public awareness, and conservation initiatives in the studied areas of the south-eastern coast of Bangladesh: (A) Tourism spot with reactional facilities; (B) concrete foot trail in the planted mangrove patch in Moheskhali; (C) incredible natural scenic beauty of the planted mangrove forest along the Moheskhali channel; (D) sea-turtle conservation initiatives on Sonadia Island and Moheskhali developed by NGOs for protecting turtle eggs and facilitating hatching; (E) public conservation awareness initiates achieved through placing billboards; (F) posters for bird conservation in public places (Photo credit: Shuvo Pal).

\section{Ecotourism and Recreation}

In the Chattagram region, according to one key informant, the Forest Department (FD) developed a plantation program three decades ago and planted about $5 \mathrm{~km}^{2}$ from Faujdarhat to South Kattali, transforming it into a beautiful mangrove forest. Several parks have been set up close to the beach under private initiatives, and thousands of tourists visit the areas, mostly on holidays and weekends. On Maoeshkhali Island, the temple of Adinath, the pagoda of the Rakhine tribe; and the quaint Buddhist temples, are tourist attractions. Sonadia Island is becoming another tourist spot due to its 
pristine nature and unspoiled beach, as one official from the forest department mentioned. According to one key informant from Sonadia Island, "For those tourists who love to visit and experience both the mountains and the sea together, Moheshkhali is a definite place for them. The beach points on the Sonadia Island are very peaceful, so tourists can visit this island to relax at the sea beach."

\section{The Religious and Rituals' Importance}

Hindu devotees gather at the Rani Rashmoni Ghat (place) at Kattali, in large numbers, to take a holy bath in the sea on 'Baruni Snan' during Madhu Krishna Tithi of Chaitra, which is the last month of the Bangla calendar. As a step towards salvation, many Hindu people believe that the cleansing of sins, diseases, and impurities can be achieved by taking a dip in the waters of holy bath places. On Moheshkhali Island, the Hindu fishermen celebrate a festival named 'Ganga-Puja' in the beach area. Many deep-sea fishermen ardently worship the goddess Ganga with the utmost respect. Those who fish in the shallow waters or a relatively risk-free environment are devoted to other goddesses [41]. Many Hindu boat owners typically coordinate worship of the goddess Ganga. The family members of the sea-going fisheries also participate in these religious events. Several Hindu fishermen are influenced by goddesses (Devi Durga and Lord Shiva) placed in the temple of Adinath [41].

\section{Education and Research Value}

The planted mangrove forest, associated saltmarsh, and coastal ecosystem of Salimpur often serve as field research sites observed during the data collection period. As Salimpur is situated close to the city, students of marine science, fisheries, forests, and botany often visit the sites for practical classes. They research mangrove and coastal ecosystems and fisheries. In Moheshkhali, researchers' attention has been noted, mostly for mangrove forest ecosystems and surveying birds. Various types of migratory birds are seen on the flood plain of Moheshkali and Sonadia Island. Moreover, the sandy beaches of Sonadia Island also support the habitat of marine reptiles. They are considered ideal breeding grounds for a variety of sea turtle species that also attract researchers' attention.

\subsection{Factors that Trigger Changes in Ecosystem Services (Based on Community Perceptions)}

According to resource-dependent respondents, several factors lead to the deterioration of ES in the region (Figure 5). These factors are unsustainable resource use and overexploitation, natural calamities, land-use change, coastal development, pollution, and governmental issues (Table 6, Figure 6).

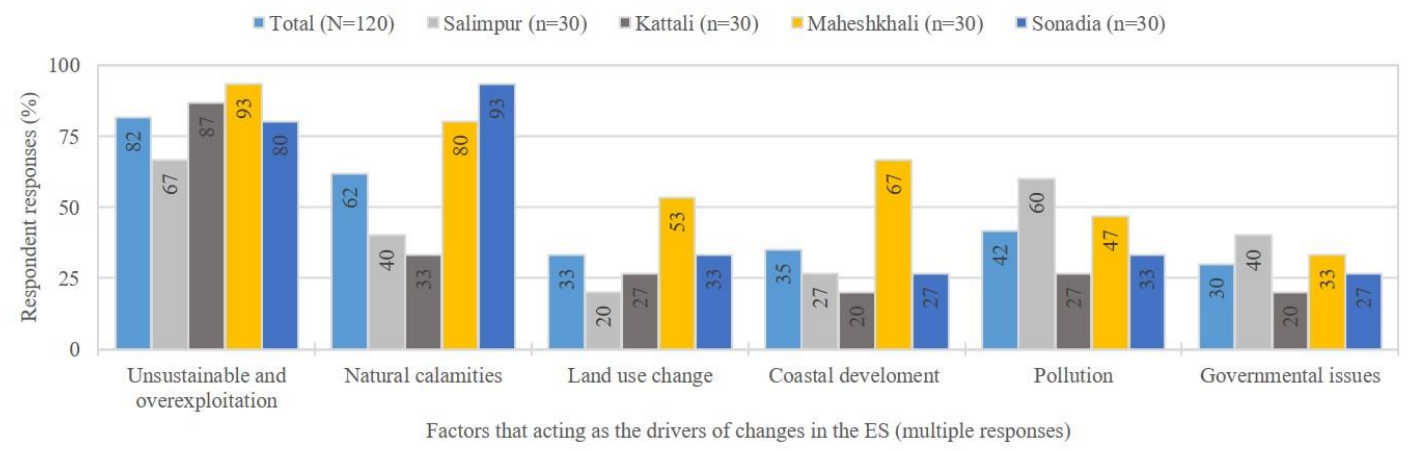

Figure 5. Community perception of factors or reasons that act as the drivers of changes in the ecosystem services along the south-eastern coast of Bangladesh. 


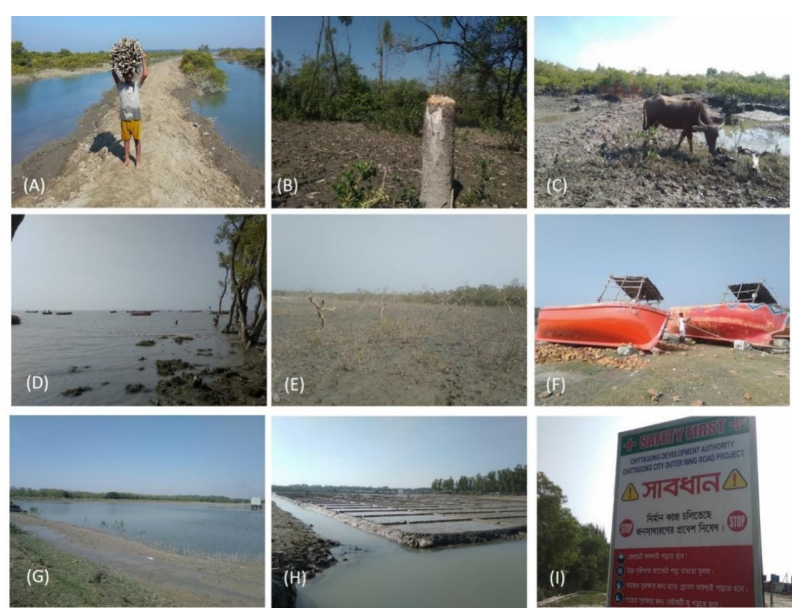

Figure 6. Anthropogenic and natural factors that trigger changes in ecosystem services in the studied south-eastern coastal areas of Bangladesh: (A) Collecting firewood, although officially prohibited; (B) illegal cutting of a pre-mature mangrove stem; (C) feral and domestic animals feed on mangrove twigs and are responsible for disturbing the new germination or establishment of mangrove plants; (D) extreme cyclone events frequently destroy the seaward periphery of the mangrove forest; (E) land-use changes and destruction of a mangrove: A bare land that was previously covered with mangrove plants; (F) coastal space for boat making, repair, net making, or even fish drying; (G) conversion of coastal space into shrimp aquaculture ponds; $(\mathbf{H})$ conversion of mangrove areas into a salt production unit; (I) signboard by the Chittagong development authority declaring the extensive development activities (Photo credit: Shuvo Pal).

\subsubsection{Unsustainable Resource Use and Overexploitation}

Most coastal resource-dependent people are poor (Appendix A, Table A2); many of them are dependent on credit (termed Dadon locally) from moneylenders (Dadonder) for buying productive assets or even meeting consumption costs. A few respondents indicated that middlemen (fishery entrepreneurs who own productive assets or provide investment capital) often push fishers to conduct illegal fishing, particularly during fishing ban periods. However, coastal fishermen face three consecutive ban periods enforced to protect juvenile hilsa shad (T. ilisha) for four months, brood hilsa shad for 22 days, and fish stock in the BOB for 65 days. Many fishing households affected are not part of the compensation scheme of a no-fishing period, which is distributed under the Vulnerable Group Feeding program of the government. One NGO official in Moheshkahli stated that "there are several regulations in effect for coastal conservation, but non-compliance of these rules is rampant." Many small-scale fishermen complained about industrial fishermen trespassing in fishing zones. Based on the Marine Fisheries Ordinance, 1983, industrial fishing trawlers are directed to fish in water with a depth greater than $40 \mathrm{~m}$. However, they often conduct fishing in the shallow coastal waters, displacing small-scale fishermen from their fishing spaces and damaging fishing equipment.

Several factors threatening mangroves were also identified during participant observation. The illegal cutting of mangrove plants for fuel, or for use as fishing poles, was noticed. Walking on mangrove forests by an increasing number of tourists is degrading grass cover, leading to erosion by rising tidal waters. Moreover, because of their free movement into the forest area, the mangrove trees' pneumatophores are being damaged. A fodder collector in Salimpur mangrove said "Visitors are responsible for the forest floor degradation. However, forest officers try to aware of best practices, but people do not listen to them. They do it at their will".

\subsubsection{Natural Calamities}

Bangladesh's coastal zone is struck by extreme cyclones almost every year, with wind speeds of up to $220 \mathrm{~km} / \mathrm{h}$ and tidal surges during the cyclone season in Bengal Bay. Shoreline forests are considered 
a buffer against, and have a protective function against, the wind actions, tidal waves, and storm surges [44]. Coastal plantations are damaged during natural calamities. The FGDs in Moheshkhali revealed that new entrants into coastal fisheries are mostly disaster-affected people who lost their assets during a cyclone or from coastal erosion, which washed away their land or other resources. Therefore, they enter fisheries for immediate survival.

\subsubsection{Land-Use Change}

The respondents' statements revealed a long practice of land-use change at the study sites, which has disturbed the coastal region's pristine nature. In the Chattagram region, besides clearing mangroves for ship-breaking yards, coastal aquaculture has also been introduced in a few places. In Moheshkali, the coastal land has been transformed into saltpan and aquaculture ponds, where shrimp and fish species' polyculture has been practiced. Expanding the traditional culture of tiger shrimp has already led to the destruction of mangroves in nearby Chakaria Sundarbans, as well as Moheskhali, Teknaf, and Sonadia Island [45]. The respondents in Moheshkhali stated several negative impacts of the conversion of Chakaria Sundarbans into commercial shrimp farms. This land-use change has severely degraded a critical habitat for local fish species. The increasing trend of erosion was also reported by several key informants, which has caused siltation in nearby Moheshkhali channels that has reduced fishable areas in which local fishermen used to fish.

\subsubsection{Coastal Development}

The government of Bangladesh has developed an initiative for carrying out extensive development activities on Moheshkhali Island to make it an energy hub of Bangladesh. Besides establishing a deep seaport, several other development projects, such as LNG pipelines, fuel terminals, and floating oil storage units, will be set up on the island. There will be fifteen coal power plants on the islands, including the large-scale transportation of commercial coal-laden vessels and full navigation along the sea-route. These may add to the impact on coastal and marine resources exerted by pollution (air and noise pollution) and solid waste generated from the coal-based power plant. The extensive development activities and associated pollution are likely to be detrimental to local mangroves, fisheries, and wildlife. While the respondents were still not fully aware of the potential impacts, one key informant, an NGO official, noted that the development activities will restrict fishermen's access to coastal space and fishing areas or even displace them. Notably, the delicate ecosystem of Sonadia Island could be disturbed by increased traffic, which would result in a loss of turtle habitats and nesting grounds for migratory birds.

\subsubsection{Pollution}

The Salimpur-Kattali region is situated close to the second largest ship scrapping yard in the world. The soil, water, and coastal environments of Chattagram district are polluted due to shipbreaking activities, mostly through various forms of discharge, such as metal fragments from ship scrapping and refuse materials, which contaminate the beach and intertidal nearshore areas, resulting in a critical condition [46]. Some fishermen from Salimpur reported that the increased docking of ships often results in their fishing spaces being occupied (locally known as Faar, where their traditional fixed fishing gear-Estuarine SetBag Net is set). The respondent fishermen in Salimpur stated that pollutants from ship breaking create a very unfavorable situation in the coastal waters, where they have been traditionally fishing for generations. Several key informants reported that influential people often encroach upon and clear mangrove forests for expanding ship breaking yards. Kattali beach and Moheshkhali Island have become popular destinations for tourists, who often leave plastic pollutants on the beach as garbage. 
Table 6. Factors or reasons acting as the drivers of ecosystem service changes along Bangladesh's south-eastern coast (based on respondents' perceptions).

\begin{tabular}{|c|c|c|}
\hline Factors & Drivers & Possible Impacts \\
\hline $\begin{array}{l}\text { Unsustainable } \\
\text { resource use and } \\
\text { overexploitation }\end{array}$ & $\begin{array}{ll}\text { - } & \text { Use of destructive fishing gear } \\
\text { - } & \text { Poverty } \\
\text { - } & \text { Trazing } \\
\text { - } & \text { Discrimination and inadequate incentives } \\
\text { - } & \text { Non-compliance of regulations } \\
\text { - } & \text { Debt bondage } \\
\text { - } & \text { Population overgrowth and overcapitalization }\end{array}$ & $\begin{array}{l}\text { - Degrading habitat quality and high proportion of catching of juveniles could result } \\
\text { in 'recruitment overfishing' as fish stocks cannot reproduce adequately, ultimately } \\
\text { jeopardizing the provision of ecosystem services. } \\
\text { Increases the complexity of nature-human interactions. A vicious cycle of poverty } \\
\text { and low alternative income-generating opportunity leads to additional pressure on } \\
\text { marine and coastal natural resource systems. } \\
\text { Illegal wildlife hunting causes biodiversity loss and habitat degradation. It } \\
\text { negatively affects the provisioning, regulation and maintenance, and cultural ES } \\
\text { and conservation. }\end{array}$ \\
\hline Natural calamities & $\begin{array}{l}\text { - } \quad \text { Global environmental changes } \\
\text { Sensitivity and exposure to extreme events and } \\
\text { limited adaptive capacities }\end{array}$ & $\begin{array}{l}\text { - Rising tidal water due to cyclonic events, possibly removing erosion and silt } \\
\text { deposition-buried mangrove propagules and seedlings, thus hampering } \\
\text { germination and regeneration. Saltwater intrusion by cyclones negatively affected } \\
\text { fish eggs, larvae, and juvenile fertility, causing high mortalities due to osmotic } \\
\text { imbalance [47]. } \\
\text { Destabilize the livelihood opportunities that force the people to be involved in } \\
\text { destructive fishing practices, e.g., shrimp post-larvae collection, and increasing } \\
\text { pressure on coastal and marine resources. }\end{array}$ \\
\hline
\end{tabular}

- Rampant violations of rules.

- People are involved in indiscriminate fishing practices to catch undersized fishes with destructive gear, such as fine-meshed nets, ESBN, Chai-crab traps, or even poison fishing.

Governmental issues

- $\quad$ Lack of capacity and coordination among different agencies

- $\quad$ Poor enforcement
- People are also involved in the illegal cutting of mangroves, logging, and poaching of wildlife.

- Governmental and managerial issues (e.g., corruption of forest officers, lack of sufficient workforce, and administrative shortcomings) are also responsible for mangrove degradation. 
Table 6. Cont.

\begin{tabular}{|c|c|c|}
\hline Factors & Drivers & Possible Impacts \\
\hline Pollution & 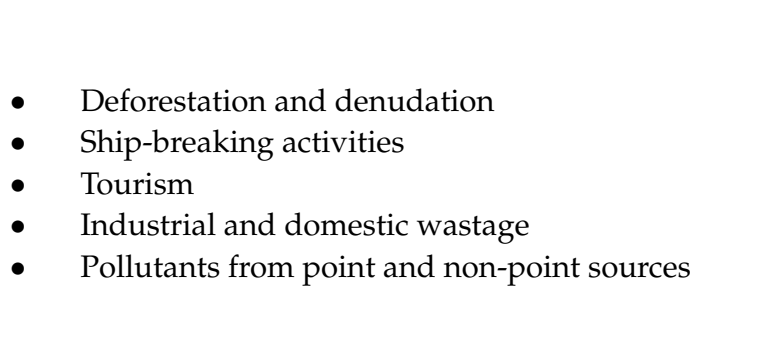 & $\begin{array}{l}\text { - Oil spill destroys the local mangroves, e.g., oil scur deposited on pneumatophores, } \\
\text { soil roots, leaves, stems, floating fruits, and macro-and microbenthic fauna. These } \\
\text { discolored waters are hard to clean-up and problematic to health involved in } \\
\text { cleaning [48]. } \\
\text { Alike Sundarbans, irresponsible touristic activities, such as waste disposal and soil } \\
\text { and water pollution, often result in overcrowded-noise pollution and disturb the } \\
\text { natural harmony of biotics in the study areas [49]. This is hampering the } \\
\text { homeostasis of sensitive habitats, such as mangroves, turtle nesting grounds } \\
\text { (Soandia Island), coral habitats, and seagrass beds. }\end{array}$ \\
\hline Land-use change & $\begin{array}{ll}\text { - } & \text { Aquaculture (coastal aquaculture and mariculture) } \\
\text { - } & \text { Economic activities } \\
\text { - } & \text { Urbanization } \\
\text { - } & \text { Erosion } \\
\text { - } & \text { Weak environmental considerations in } \\
& \text { land-use policies }\end{array}$ & $\begin{array}{l}\text { - Reduce mangrove cover as encores for aquaculture activities and conversion of } \\
\text { coastal land into salt pans. Farm effluents cause deterioration of water quality, e.g., } \\
\text { discoloration, bad smell, etc., and have detrimental effects on adjacent mangrove } \\
\text { macrobenthos, reducing the density of various mangrove taxa [14]. } \\
\text { - Construction of numerous dikes and polders increased sedimentation by deposition } \\
\text { of silts in riverbed siltation, resulting in decreased fishable areas; a change of fish } \\
\text { populations, migration paths, spawning areas, and capture compositions; and } \\
\text { obstacles to navigation in waterways. }\end{array}$ \\
\hline Coastal development & $\begin{array}{l}\text { - Governance policy for blue growth and } \\
\text { economic development } \\
\text { - Weak implementation of existing coastal } \\
\text { regulations and policies }\end{array}$ & $\begin{array}{l}\text { - Recent large-scale development activities and industrial development in the nearby } \\
\text { portion of the BOB (Matarbari deep seaport) have caused pollution and habitat } \\
\text { degradation and biodiversity loss. } \\
\text { Coastal development activities hampering the homeostatic state of natural biomes, } \\
\text { e.g., may be harmful to the sea turtle, and their nesting habitat is reduced by and in } \\
\text { conflict with conservation perspectives. }\end{array}$ \\
\hline
\end{tabular}




\subsubsection{Governmental Issues}

Different resource management authorities are located in various government departments, where a lack of coordination that may cause weak governance is apparent. The Department of Environment has the power to take steps for the coastal and land ecosystem. The Department of Forest has the jurisdiction to manage mangrove forests. The Department of Fisheries (DoF) has the responsibility of governing marine and coastal fishery resources. The duties of controlling and preventing marine pollution also rest on different departments of the governmental body. Each entity has various regulations, which sometimes contradict each other. For example, elasmobranch species are considered protected wildlife species by forest-related rules. However, whilst many fishermen harvest these species, fishery officers do not have the power to ban this practice as fishery-related regulations lack this provision. Almost all governmental bodies suffer from a lack of workforce and other logistical support (e.g., vigilance equipment and vehicles). Therefore, the implementation of monitoring and surveillance is an uphill task [50]. Consequently, non-compliance is rampant, as indicated by one key informant in Moheshkhali.

\section{Discussion and Conclusions}

The findings of the present study suggest that local communities on the southeast coast exploit several ecosystem services, mainly provisioning services, such as food, medicine, fodder, timber, and cultural services, such as spiritual functions, recreation, and tourism. Provisioning services are indissolubly linked to the employment and income of local communities. Many of these people, particularly caste-based Hindu fishermen along the south-eastern coast, are related to the fishery ecosystem through their caste-based occupation [51]. Many of these households depend on coastal ecosystem services for daily food, income, and traditional medicine and cultural heritage. Some of the ES provide benefits to broader society [52]. There is a growing recognition that planted mangroves also serve as barriers to the risks of tsunamis, cyclones, and other natural disasters [6]. This assessment of ecosystem services could positively shape public perceptions of the importance of coastal ecosystem services. This is necessary as the coastal zone has become a hub of competing interests of blue growth initiatives, coastal development, and traditional livelihoods.

Similar to global situations, coastal ecosystem services in Bangladesh face different threats, many of which are from an anthropogenic origin. Among these threats, some are driven by the government's neoliberal policies that embrace economic development at the cost of environmental and common property rights, such as ship-breaking activities on the Chattagram coast and the conversion of Chakaria mangrove forest for introducing shrimp farming in Cox's Bazar region. The recently introduced blue growth agenda has also been criticized as a risk factor for traditional coastal communities. Globally, the Blue Growth and Blue Economy agenda appears to ignore small-scale fisheries, with little or no reference in the discussion, and thus puts them in more disadvantaged situations [36]. While Bangladesh is yet to achieve fully functional blue growth initiatives, coastal small-scale fishing communities are already facing pressures from coastal development interventions. The Bangladesh government has emphasized the development and sustainable use of marine and coastal resources for achieving blue growth and the UN SDG 14 (Life Below Water). The government has set up Blue Economy Cell; each department has developed strategies for achieving respective SDG goals [43]. Given that coastal fishing communities are mostly socially excluded, with very poor political representation, there are risks that they will be left behind or even further marginalized as an outcome of the ongoing development process on the coast, as was experienced in the 1990s during the expansion of coastal aquaculture. During 1985-1988, the World Bank granted funds to expand shrimp farming that ultimately converted patches of mangrove forests into privatized ponds to culture export-oriented shrimp species [53]. This privatization of common property marginalized many of the coastal poor, who usually live on government-owned khas land and conduct fishing in the coastal floodplains, many of which were later converted into shrimp ponds [54]. 
There is criticism that this neoliberal thinking has often led to justifying the introduction of "ocean grabbing" in energy development, aquaculture, and tourism [55], which is also manifested in this study. The fishery stock on the Chattagram coast is impacted by ship-breaking activities on the water, which degrade the mangrove ecosystem on the coast [46]. The traditional tenure rights of coastal fishermen are also breached by industrial fishing [51]. The situation is likely to worsen as the government focuses on expanding industrial fishing in the bay as a driver of blue growth. The caste-based fishermen have limited skill sets or opportunities for alternative occupations [41]. Any changes that limit their access to coastal ecosystem services are likely to result in them being further marginalized. Tourism is a crucial neoliberal conservation activity in many tropical mangrove areas. It can promote conservation by promoting responsible travel that preserves environmental characteristics, while empowering local communities and improving sustainable livelihoods [56]. However, irresponsible, and poorly regulated tourism can also result in more harm than benefits. It was shown that increasingly growing mangrove ecotourism activities in Langkawi, Malaysia, were causing degradation and other negative impacts on the ecosystem. Simultaneously, it may be premature to assess the potential effects of energy sector development in Moheshkhali. However, it can safely be said that access to the government-owned coastal space is likely to be hampered or even restricted for the coastal fishermen. They presently carry out different economic activities for their livelihoods, income, employment, and cultural reasons. Overall, the land-use change will compromise the quality of ecosystem services in the region. For example, in Asia, drastic land transformation has occurred in recent decades, resulting in soil degradation [43] and the loss of ecosystem services and the economy [57].

The government needs to encourage sustainable development initiatives that fully appreciate the values of coastal ecosystem services and support the current and potential contributions of small-scale fisheries in the country's development, whilst achieving all the SDGs [36]. When any blue growth agenda might interact with small-scale fishery activities and spaces, it should include small-scale fishermen as stakeholders to address power imbalances and equity [58]. This is where procedural equity should be ensured through small-scale fishermen's access to decision-making when they are vulnerable to any development intervention's negative consequences. Steps should be taken to ensure environmental justice so that marginal communities do not suffer from disproportionate effects of industrial pollutants, hazards, or waste disposal that compromise the health and well-being of fishing community members [59].

Besides external drivers, coastal ecosystem services are also facing threats deriving from resource-user behavior. Among these threats, over-exploitation and destructive fishing practices are a significant threat to resource conservation. The success of resource conservation is highly related to decentralizing responsibilities to resource-dependent communities [60]. Therefore, ensuring procedural equity (i.e., the inclusive and effective participation of all stakeholders) in rules and decision-making processes in coastal management is also essential. If small-scale coastal fishermen and other actors shoulder the responsibility of making decisions and managing resources, they are less likely to violate the regulations and more likely to foster responsible attitudes towards conservation [61]. As such, the engagement of key stakeholders in co-management approaches should be given vital consideration. Procedural legitimacy (concerning an open, transparent, and inclusive process of decision-making via the effective participation of all relevant stakeholders) is closely linked to fairness perceptions [62]. Ensuring both could help in compliance with regulations. No such legitimacy exists in coastal fishery management on the south-eastern coast of Bangladesh.

To this end, the Small-Scale Fisheries (SSF) Guidelines [63] are considered an appropriate and timely instrument for initiating policy change to deliver social justice to small-scale fisheries [36]. The SSF Guidelines recognize the necessity of the responsible and sustainable use and management of aquatic biodiversity and natural resources. The guidelines also ask the states, according to their legislation, to ensure secure, equitable, and socially and culturally appropriate tenure rights of fishing areas and adjacent land areas for small-scale fishermen, thus facilitating recognition equity. As stipulated 
in the guidelines, it is also essential to ensure the prevention of small-scale fishing communities from being arbitrarily evicted because of a large-scale development project. Before developing such a project, the state should consider studying social, economic, and environmental impacts and carry out significant and meaningful consultations with the communities within the scope of national jurisdiction (Guidelines 5.10). Procedural equity can further be ensured by implementing the guidelines (5.15) that ask to "facilitate, train and support small-scale fishing communities to participate in and take responsibility for, taking into consideration their legitimate tenure rights and systems, the management of the resources" on which small-scale fishers depend for their livelihoods and well-being. Accordingly, small-scale fishing communities should be promoted and involved in different participatory management systems (e.g., co-management). To make the coastal communities receptive to improved governance mechanisms, the state should also encourage investment in human resource development, for example, health, education, digital inclusion, technical skills, and awareness building, as stipulated in Guidelines 6.2. In line with the Guidelines (9.3), steps should address pollution, coastal erosion, and the loss of coastal habitats due to human-induced external factors, as this disturbance degrades the coastal ecosystem services. As small-scale fishermen are considered as being among the most vulnerable professional groups, the guidelines also ask for community consultation, in order to work towards climate change adaptation, mitigation, emergency responses, and disaster preparedness (Guidelines 9.7). Considering all of these points, the SSF Guidelines are a tool for achieving several SDGs for small-scale fishing communities and the 2030 Agenda for Sustainable Development [63].

Author Contributions: M.M.I.: Conceptualization, draft preparation, and editing; S.P.: Fieldwork and draft preparation; M.M.H.: Analysis, review, and editing; M.M.H.M.: Review and editing; P.S.: Review and editing. All authors have read and approved the final version. All authors have read and agreed to the published version of the manuscript.

Funding: This research was funded by "Too Big to Ignore: Global Partnership for Small-Scale Fisheries Research" funded by the Social Sciences and Humanities Research Council of Canada (grant number 895-2011-1011). The APC was funded by the University of Applied Sciences Magdeburg-Stendal. For M.M.I., research funding was provided by the Ocean Frontier Institute, through an award from the Canada First Research Excellence Fund.

Acknowledgments: We acknowledge the respondents that participated in this study, as well as the very useful comments and suggestions provided by the anonymous reviewers, which helped to improve the manuscript.

Conflicts of Interest: The authors declare no conflict of interest.

\section{Appendix A Coastal Ecosystem Services, Social Equity, and Blue Growth: A Case Study from South-Eastern Bangladesh}

\section{Summary of Queries of the Semi-Structured Questionnaire Administered in This Study}

Section A. Includes questions related to respondents' background, personal and family information, respondents' households, and their occupational and socioeconomic status, such as:

- Name, address, age, sex, marital status, religion, literacy, family size, household assets, cooking facilities, housing conditions, occupational status, source of income, monthly and annual income, and amount of income (percentages) obtained from the coastal and marine natural resource systems, etc.

Section B: Includes queries on the uses of available coastal resources (provisioning ecosystems services) within their household.

- What are the benefits you get from the mangrove resources? Fuelwood/timber for construction/fodder for domestic animals/food (edible portion of mangrove trees)/medicinal /other use (fisheries and mangrove-fishbait)/food (other sources).

- What are the preferred species/which part is for which purpose and how do you collect selected mangrove species? 
- What are the benefits you get from the fishery resources? Food/medicine/others.

- What are the preferred species/which species are for which purpose and how do you collect/harvest selected fishery species?

Section C: Includes queries on the available cultural ecosystem services associated with coastal resources.

- What are the cultural ecosystem services available in the study areas? Ecotourism and recreation/the religious and ritual importance/education and research values/others.

Section D: This section includes questions about factors that trigger changes in the coastal ecosystem's services, equity, and conservation perspectives.

- Have you perceived any changes (based on your experience) in the coastal natural resources (mangrove forest and fisheries) over the past 10-20 years? Yes/no/no comment (if yes).

- What are the factors that cause changes in the coastal natural resource systems and their ecosystem services (multiple options)? Unsustainable use and overexploitation/natural calamities/governmental issues/pollution/land-use change/coastal development.

- Would you please state your views about the right and access to resources, and your involvement in the decision-making process and overall existing management regimes?

- What is your suggestion for conserving the coastal (mangrove and fisheries) resources? 
Table A1. Demographic, socioeconomic, and livelihood data on the stakeholders in the study areas of coastal Bangladesh.

\begin{tabular}{|c|c|c|c|c|}
\hline \multirow{2}{*}{$\begin{array}{l}\text { Attributes/Criteria with a Brief Description } \\
\text { (Number of Respondents, Frequency or \%) }\end{array}$} & \multicolumn{2}{|c|}{ Chattagram $(n=60)$} & \multicolumn{2}{|c|}{ Cox's Bazar $(n=60)$} \\
\hline & Salimpur $(n=30)$ & Kattali $(n=30)$ & Moheshkhali $(n=30)$ & Sonadia $(n=30)$ \\
\hline \multicolumn{5}{|l|}{ Age (years) class (\% respondents) } \\
\hline$<20$ & 0 & 20 & 0 & 0 \\
\hline $20-29$ & 6.67 & 40 & 26.67 & 20 \\
\hline $30-39$ & 46.67 & 40 & 33.33 & 33.33 \\
\hline $40-49$ & 26.67 & 0 & 0 & 13.33 \\
\hline $50-59$ & 20 & 0 & 13.33 & 20 \\
\hline$>60$ & 0 & 0 & 26.67 & 13.33 \\
\hline \multicolumn{5}{|l|}{ Education Status (\% respondents) } \\
\hline Illiterate & 26.67 & 13.33 & 26.67 & 26.67 \\
\hline Can sign only & 26.67 & 20 & 26.67 & 6.67 \\
\hline Primary & 26.67 & 13.33 & 26.67 & 13.33 \\
\hline Secondary & 13.33 & 26.67 & 13.33 & 33.33 \\
\hline SSC & 6.67 & 20 & 13.33 & 20 \\
\hline HSC & 0 & 6.67 & 0 & 0 \\
\hline Graduate & 0 & 0 & 0 & 0 \\
\hline \multicolumn{5}{|l|}{ Main Occupation (Frequency) } \\
\hline Fisher & 12 & 16 & 18 & 14 \\
\hline Snail and oyster collector & 0 & 0 & 4 & 4 \\
\hline Timber/firewood collector & 6 & 0 & 0 & 0 \\
\hline Fish trader & 4 & 4 & 0 & 2 \\
\hline Cattle rearing & 6 & 4 & 0 & 4 \\
\hline $\begin{array}{c}\text { Others, e.g., day labor, ancillary fishery activities, e.g., } \\
\text { net repairing }\end{array}$ & 2 & 6 & 8 & 6 \\
\hline \multicolumn{5}{|c|}{ Level of Monthly Income (BDT) (\% Respondents) } \\
\hline$<5000$ & 0 & 0 & 6.67 & 0 \\
\hline $5000-10,000$ & 13.33 & 33.33 & 73.33 & 53.33 \\
\hline $10,000-1,5000$ & 60 & 60 & 20 & 46.67 \\
\hline$>15,000$ & 26.67 & 6.67 & 0 & 0 \\
\hline \multicolumn{5}{|c|}{ The Portion of Income that Comes from Coastal Natural Resource-Dependent Occupation (\% Respondents) } \\
\hline$<10 \%$ & 6.67 & 0 & 6.67 & 0 \\
\hline $10-30 \%$ & 6.67 & 6.67 & 13.33 & 6.67 \\
\hline $30-50 \%$ & 13.33 & 13.33 & 6.67 & 0 \\
\hline
\end{tabular}


Table A1. Cont.

\begin{tabular}{|c|c|c|c|c|}
\hline \multirow{2}{*}{$\begin{array}{l}\text { Attributes/Criteria with a Brief Description } \\
\text { (Number of Respondents, Frequency or \%) }\end{array}$} & \multicolumn{2}{|c|}{ Chattagram $(n=60)$} & \multicolumn{2}{|c|}{ Cox's Bazar $(n=60)$} \\
\hline & Salimpur $(n=30)$ & Kattali $(n=30)$ & Moheshkhali $(n=30)$ & Sonadia $(n=30)$ \\
\hline $50-70 \%$ & 20 & 6.67 & 6.67 & 13.33 \\
\hline $70-90 \%$ & 26.67 & 46.67 & 20 & 60 \\
\hline$>90 \%$ & 20 & 26.67 & 46.67 & 20 \\
\hline \multicolumn{5}{|l|}{ Housing Condition (Frequency) } \\
\hline Earthen (clay/mud) & 0 & 0 & 6 & 4 \\
\hline Natural materials, e.g., wood, thatch, bamboo, straw & 0 & 0 & 2 & 2 \\
\hline Tin-shade (iron sheets) & 24 & 22 & 20 & 24 \\
\hline $\begin{array}{l}\text { Semi building, building, cement blocks/concrete/bricks } \\
\text { (Pucca) }\end{array}$ & 4 & 8 & 2 & 0 \\
\hline \multicolumn{5}{|l|}{ Housing Materials (Frequency) } \\
\hline Wall & 0 & 0 & 0 & 0 \\
\hline Earthen & 6 & 0 & 8 & 2 \\
\hline Wood & 2 & 0 & 2 & 2 \\
\hline Tin & 12 & 12 & 6 & 10 \\
\hline Cemented brick & 6 & 14 & 0 & 10 \\
\hline Others & 4 & 4 & 14 & 6 \\
\hline \multicolumn{5}{|l|}{ Floor } \\
\hline Earthen (clay/mud) & 20 & 8 & 26 & 18 \\
\hline Natural materials, e.g., wood, bamboo & 0 & 0 & 0 & 0 \\
\hline Cemented (Pucca) & 10 & 22 & 4 & 12 \\
\hline \multicolumn{5}{|l|}{ Roof } \\
\hline Natural materials, e.g., thatch, bamboo, straw & 0 & 0 & 6 & 4 \\
\hline Tin-shade (iron sheets) & 26 & 30 & 24 & 26 \\
\hline Concrete $($ Pucca) & 2 & 0 & 0 & 0 \\
\hline
\end{tabular}


Table A2. The available fishery species recorded in the study areas in the coastal ecosystems of the south-eastern coast of Bangladesh.

\begin{tabular}{|c|c|c|c|c|c|c|c|c|c|c|c|c|}
\hline \multirow{2}{*}{ Types of Fishery Resources } & \multirow{2}{*}{$\begin{array}{c}\text { Number of } \\
\text { Species }\end{array}$} & \multicolumn{7}{|c|}{ Global IUCN Status ${ }^{1}$} & \multicolumn{4}{|c|}{ Population Trend } \\
\hline & & NE & LC & NT & VU & EN & CR & DD & Stable & Decrease & Unknown & Not Reported \\
\hline Chondrichthyes & 10 & 2 & 0 & 4 & 3 & 1 & 0 & 0 & 0 & 7 & 1 & 2 \\
\hline Bony fish/fin-fishes & 115 & 53 & 52 & 3 & 0 & 0 & 0 & 7 & 11 & 12 & 38 & 53 \\
\hline Shrimps/prawns and lobsters & 6 & 5 & 1 & 0 & 0 & 0 & 0 & 0 & 0 & 0 & 1 & 5 \\
\hline Crabs & 6 & 5 & 0 & 0 & 0 & 0 & 0 & 1 & 0 & 0 & 1 & 5 \\
\hline
\end{tabular}

${ }^{1}$ Global IUCN status of the species and global population trends represented here are according to the IUCN Red List of Threatened Species (IUCN 2019). Categories of IUCN status: Data Deficient (DD), Least Concern (LC), Near Threatened (NT), Vulnerable (VU), Endangered EN), Critically Endangered (CR), and Not Evaluated (NE): Taxon that has not yet been evaluated for the IUCN Red List.

Table A3. Planted mangrove plant species found on the south-eastern coast of Bangladesh (Source: Modified after Arefin et al., 2017).

\begin{tabular}{|c|c|c|c|c|c|}
\hline Order & Family & Botanic/Scientific Name & Common English Name & Local Name & Plant Types \\
\hline Myrtales & Lythraceae & Sonneratia apetala Buch.Ham. & Mangrove apple & Keora & Tree \\
\hline Lamiales & Acanthaceae & Avicennia alba Blume & White mangrove & Sada Baen & Shrub \\
\hline Lamiales & Acanthaceae & Avicennia officinalis L. & Indian mangrove & Kala Baen & Shrub \\
\hline Lamiales & Acanthaceae & Acanthus ilicifolius L. & Holy mangrove & Hargoza & Shrub \\
\hline Malpighiales & Euphorbiaceae & Excoecaria agallocha $\mathrm{L}$. & Milky mangrove & Gewa & Shrub \\
\hline Boraginales & Boraginaceae & Heliotropium curassavicum L. & Salt heliotrope & Hatisur & Herb \\
\hline
\end{tabular}




\section{References}

1. Daily, G.C. Valuing and Safeguarding Earth's Life Support Systems. Natures Services: Societal Dependence on Natural Ecosystems; Island Press: Washington, DC, USA, 1997; pp. 365-374.

2. Turner, R.K.; Schaafsma, M. Coastal zones ecosystem services. Valuat. Ecosyst. Serv. 2015, 9, 59-75.

3. Farhan, A.R.; Lim, S. Improving vulnerability assessment towards Integrated Coastal Zone Management (ICZM): A case study of small islands in Indonesia. J. Coast. Conserv. 2013, 17, 351-367. [CrossRef]

4. Fisher, B.; Turner, R.K.; Morling, P. Defining and classifying ecosystem services for decision making. Ecol. Econ. 2009, 68, 643-653. [CrossRef]

5. Steffen, W.; Rockström, J.; Richardson, K.; Lenton, T.M.; Folke, C.; Liverman, D.; Donges, J.F. Trajectories of the Earth System in the Anthropocene. Proc. Natl. Acad. Sci. USA 2018, 115, 8252-8259. [CrossRef]

6. Barbier, E.B. Natural barriers to natural disasters: Replanting mangroves after the tsunami. Front. Ecol. Environ. 2006, 4, 124-131. [CrossRef]

7. Barbier, E.B.; Heal, G.M. Valuing ecosystem services. Econ. Voice 2006, 3. [CrossRef]

8. Cesar, H.; Burke, L.; Pet-Soede, L. The Economics of Worldwide Coral Reef Degradation. Cesar Environmental Economics Consulting (CEEC). Available online: http://pdf.wri.org/cesardegradationreport100203.pdf (accessed on 5 April 2020).

9. UN. Transforming Our World: The 2030 Agenda for Sustainable Development; United Nations: New York, NY, USA, 2015.

10. Berghöfer, A.; Brown, C.; Bruner, A.; Emerton, L.; Esen, E.; Geneletti, D.; Kosmus, M.; Kumar, R.; Lehmann, M.; Morales, F.L.; et al. In-creasing the Policy Impact of Ecosystem Service Assessments and Valuations-Insights from Practice; Helmholtz-Zentrum für Umweltforschung (UFZ) GmbH, Leipzig, and Deutsche Gesellschaft für Internatio-nale Zusammenarbeit (GIZ) GmbH: Eschborn, Germany, 2016; p. 31.

11. Busch, M.; La Notte, A.; Laporte, V.; Erhard, M. Potentials of quantitative and qualitative approaches to assessing ecosystem services. Ecol. Indic. 2012, 21, 89-103. [CrossRef]

12. Islam, M.M.; Shamsuddoha, M. Coastal and marine conservation strategy for Bangladesh in the context of achieving blue growth and sustainable development goals (SDGs). Environ. Sci. Policy 2018, 87, 45-54. [CrossRef]

13. GoB-FAO. Master Plan for Agricultural Development in the Southern Region of Bangladesh. In the Government of the Peoples' Republic of Bangladesh \& Food and Agricultural Organization of the United Nations. Rome: Food and Agriculture Organization of the United Nations. Available online: http: //www.fao.org/3/a-au752e.pdf (accessed on 20 March 2020).

14. Hussain, M.G.; Failler, P.; Karim, A.A.; Alam, M.K. Major opportunities of blue economy development in Bangladesh. J. Indian Ocean Reg. 2018, 14, 88-99. [CrossRef]

15. Patil, P.G.; Virdin, J.; Diez, S.M.; Roberts, J.; Singh, A. Toward A Blue Economy: A Promise for Sustainable Growth in the Caribbean; World Bank: Washington, DC, USA, 2016.

16. General Economics Division (GED). Seventh Five Year Plan (FY2016-2020): Accelerating Growth, Empowering Citizens; Planning Commission, Government of the People's Republic of Bangladesh: Dhaka, Bangladesh, 2015.

17. Patil, P.G.; Virdin, J.; Colgan, C.S.; Hussain, M.G.; Failler, P.; Veigh, T. Initial measures of the economic activity linked to Bangladesh's ocean space, and implications for the country's blue economy policy objectives. J. Ocean Coast. Econ. 2019, 6, 2. [CrossRef]

18. Pamalakaya-Pilipinas. Bluer Than Blue Economy: Fisherfolk Group Say no to Apec's Blue Economy Strategy. Manila: Pamalakaya-Pilipinas National Federation of Small Fisherfolk Organizations in the Philippines. Available online: https://pamalakayaweb.wordpress.com/2015/10/07/bluer-than-blue-economy-fisherfolkgroup-say-no-to-apecs-blue-economy-strategy/ (accessed on 7 April 2020).

19. Bennett, N.J.; Govan, H.; Satterfield, T. Ocean grabbing. Mar. Policy 2015, 57, 61-68. [CrossRef]

20. Barbesgaard, M. Blue growth: Savior or ocean grabbing? J. Peasant Stud. 2018, 45, 130-149. [CrossRef]

21. Ruckelshaus, M.; Doney, S.C.; Galindo, H.M.; Barry, J.P.; Chan, F.; Duffy, J.E.; Knowlton, N. Securing ocean benefits for society in the face of climate change. Mar. Policy 2013, 40, 154-159. [CrossRef]

22. Martín-López, B.; Gómez-Baggethun, E.; García-Llorente, M.; Montes, C. Trade-offs across value-domains in ecosystem services assessment. Ecol. Indicat. 2014, 37, 220-228. [CrossRef]

23. Lillebø, A.I.; Pita, C.; Rodrigues, J.G.; Ramos, S.; Villasante, S. How can marine ecosystem services support the Blue Growth agenda? Mar. Policy 2017, 81, 132-142. [CrossRef] 
24. Burkhard, B.; Santos-Martin, F.; Nedkov, S.; Maes, J. An operational framework for integrated Mapping and Assessment of Ecosystems and their Services (MAES). One Ecosyst. 2018, 3, e22831. [CrossRef]

25. Papry, R.I. Status of coastal plantation in the Chattagram coastal forest division. IOSR J. Environ. Sci. Toxicol. Food Technol. 2014, 8, 79-83. [CrossRef]

26. Hena, M.A.; Aysha, A.; Ashraful, M.A.K.; Sharifuzzaman, S.M. Distribution of aquatic macrophytes in the coastal area of Salimpur, Chattagram, Bangladesh. CMU. J. Nat. Sci. 2010, 9, 273-279.

27. Hena, A.M.K.; Sidik, A.B.J.; Aysha, H.; Ahasan, F.T. Estuarine macrophytes at Bakkhali, Cox's Bazar, Bangladesh with reference to mangroves diversity. Chiang Mari. J. Sci. 2013, 40, 556-563.

28. Arefin, M.S.; Hossain, M.K.; Hossain, M.A. Plant diversity of Sonadia Island An ecologically critical area of South-East Bangladesh. Bangladesh J. Plant Taxon. 2017, 24, 107-116. [CrossRef]

29. Hena, M.A.; Short, F.T.; Sharifuzzaman, S.M.; Hasan, M.; Rezowan, M.; Ali, M. Salt marsh and seagrass communities of Bakkhali Estuary, Cox's Bazar, Bangladesh. Estuar. Coast. Shelf Sci. 2007, 75, 72-78. [CrossRef]

30. McDermott, M.; Mahanty, S.; Schreckenberg, K. Examining equity: A multidimensional framework for assessing equity in payments for ecosystem services. Environ. Sci. Policy 2013, 33, 416-427. [CrossRef]

31. Pascual, U.; Muradian, R.; Rodríguez, L.C.; Duraiappah, A. Exploring the links between equity and efficiency in payments for environmental services: A conceptual approach. Ecol. Econ. 2010, 69, 1237-1244. [CrossRef]

32. MEA. Ecosystems and Human Well-Being: Synthesis; World Resources Institute: Washington, DC, USA, 2005.

33. Lehmann, I.; Martin, A.; Fisher, J.A. Why Should Ecosystem Services Be Governed to Support Poverty Alleviation? Philosophical Perspectives on Positions in the Empirical Literature. Ecol. Econ. 2018, 149, 265-273. [CrossRef]

34. Billé, R.; Lapeyre, R.; Pirard, R. Biodiversity conservation and poverty alleviation: A way out of the deadlock? SAPI EN. S. Surv. Perspect. Integr. Environ. Soc. 2012. Available online: http://journals.openedition.org/ sapiens/1452 (accessed on 27 September 2020).

35. FAO. Report of the Workshop on Strategic Data Policies, Rome, Italy, 21-22 September 2015; FAO Fisheries and Aquaculture Report No. 1180: Rome, Italy, 2018.

36. Chuenpagdee, R. Blue justice for small-scale fisheries: What, why and how. In Blue Justice for Small-Scale Fisheries: A Global Scan; Kerezi, V., Kinga Pietruszka, D., Chuenpagdee, R., Eds.; TBTI Global Publication Series: St. John's, NL, Canada, 2020.

37. Eikeset, A.M.; Mazzarella, A.B.; Davíðsdóttir, B.; Klinger, D.H.; Levin, S.A.; Rovenskaya, E.; Stenseth, N.C. What is blue growth? The semantics of "Sustainable Development" of marine environments. Mar. Policy 2018, 87, 177-179. [CrossRef]

38. Pascual, U.; Phelps, J.; Garmendia, E.; Brown, K.; Corbera, E.; Martin, A.; Gomez-Baggethun, E.; Muradian, R. Social equity matters in payments for ecosystem services. Bioscience 2014, 64, 1027-1036. [CrossRef]

39. Cisneros-Montemayor, A.M.; Moreno-Báez, M.; Voyer, M.; Allison, E.H.; Cheung, W.W.; Hessing-Lewis, M.; Oyinlola, M.A.; Singh, G.G.; Swartz, W.; Ota, Y. Social equity and benefits as the nexus of a transformative Blue Economy: A sectoral review of implications. Mar. Policy 2019, 109, 103702. [CrossRef]

40. Islam, M.M.; Jentoft, S. Creating an enabling environment to support disaster risk reduction in the context of the SSF Guidelines: A case study from Bangladesh. In Securing Sustainable Small-scale Fisheries: Sharing Good Practices from around the World; FAO: Rome, Italy, 2019; pp. 87-106.

41. Deb, A.K.; Haque, C.E. 'Every mother is a mini-doctor': Ethnomedicinal uses of fish, shellfish and some other aquatic animals in Bangladesh. J. Ethnopharmacol. 2011, 134, 259-267. [CrossRef]

42. Mariam, H. Micronutrient Contents of Heritiera fomes Species at Three Saline Zones of the Sundarban Mangrove Forest, Bangladesh. Open Access Libr. J. 2020, 7, 1.

43. Sarker, S.; Bhuyan, M.A.H.; Rahman, M.M.; Islam, M.A.; Hossain, M.S.; Basak, S.C.; Islam, M.M. From science to action: Exploring the potentials of Blue Economy for enhancing economic sustainability in Bangladesh. Ocean Coast. Manag. 2018, 157, 180-192. [CrossRef]

44. Lyche, M. Protection of Sea Dykes through Planting of Trees. Appraisal of the Forestry Component of WFP Project Vietnam; World Food Programme: Rome, Italy, 1991; p. 9617.

45. Rahman, M.M.; Giedraitis, V.R.; Lieberman, L.S.; Akhtar, M.T.; Taminskienè, V. Shrimp cultivation with water salinity in Bangladesh: The implications of an ecological model. Univ. J. Public Health 2013, 1, 131-142.

46. Hossain, M.M.M.; Islam, M.M. Ship Breaking Activities and Its Impact on the Coastal Zone of Chittagong, Bangladesh: Towards Sustainable Management; Advocacy \& Publication Unit, Young Power in Social Action (YPSA): Chittagong, Bangladesh, 2006. 
47. Islam, M.M.; Chuenpagdee, R. Nomadic fishers in the hilsa sanctuary of Bangladesh: The importance of social and cultural values for wellbeing and sustainability. In Social Wellbeing and the Values of Small-Scale Fisheries; Springer: Cham, Switzerland, 2018; pp. 195-216.

48. Duke, N.C. Oil spill impacts on mangroves: Recommendations for operational planning and action based on a global review. Mar. Pollut. Bull. 2016, 109, 700-715. [CrossRef]

49. Islam, M.M.; Sunny, A.R.; Hossain, M.M.; Friess, D.A. Drivers of mangrove ecosystem service change in the Sundarbans of Bangladesh. Singap. J. Trop. Geogr. 2018, 39, 244-265. [CrossRef]

50. Islam, M.M.; Shamsuzzaman, M.M.; Mozumder, M.M.; Xiangmin, X.; Ming, Y.; Jewel, M.A. Exploitation and conservation of coastal and marine fisheries in Bangladesh: Do the fishery laws matter? Mar. Policy 2017, 76, 143-151. [CrossRef]

51. Jentoft, S.; Onyango, P.; Islam, M.M. Freedom and poverty in the fishery commons. Int. J. Commons 2010, 4, 345-366. [CrossRef]

52. Islam, M.M.; Hossain, M.M. Community dependency on the ecosystem services from the Sundarbans mangrove wetland in Bangladesh. In Wetland Science; Springer: New Delhi, India, 2017; pp. 301-316.

53. Hossain, M.; Lin, C.K.; Hussain, M.Z. Goodbye Chakaria Sunderban: The Oldest Mangrove Forest. SWS Bull. 2001, 18, 19-22. [CrossRef]

54. Islam, M.M.; Chuenpagdee, R. Negotiating risk and poverty in mangrove fishing communities of the Bangladesh Sundarbans. Marit. Stud. 2013, 12, 7. [CrossRef]

55. Pinkerton, E.; Davis, R. Neoliberalism, and the politics of enclosure in North American small-scale fisheries. Mar. Policy 2015, 61, 303-312. [CrossRef]

56. Thompson, B.S.; Gillen, J.; Friess, D.A. Challenging the principles of ecotourism: Insights from entrepreneurs on environmental and economic sustainability in Langkawi, Malaysia. J. Sustain. Tour. 2018, 26, 257-276. [CrossRef]

57. Wu, K.Y.; Ye, X.Y.; Qi, Z.F.; Zhang, H. Impacts of land use/land cover change and socioeconomic development on regional ecosystem services: The case of fast-growing Hangzhou metropolitan area, China. Cities 2013, 31, 276-284. [CrossRef]

58. Jentoft, S. Life above Water: Essays on Human Experiences of Small-Scale Fisheries; TBTI Global: St. John's, NL, Canada, 2019.

59. FAO. Voluntary Guidelines for Securing Sustainable Small-Scale Fisheries. In The Context of Food Security and Poverty Eradication; Food and Agriculture Organization of the United Nations: Rome, Italy, 2015; p. 18.

60. Ostrom, E. Governing the Commons: The Evolution of Institutions for Collective Action; Cambridge University Press: New York, NY, USA, 1990.

61. Ban, N.C.; Hansen, G.J.A.; Jones, M.; Vincent, A.C.J. Systematic marine conservation planning in data-poor regions: Socioeconomic data is essential. Mar. Policy 2009, 33, 794-800. [CrossRef]

62. Sutinen, J.G.; Kuperan, K. A socio-economic theory of regulatory compliance. Int. J. Soc. Econ. 1999, 26, 174-193. [CrossRef]

63. FAO. Voluntary Guidelines for Securing Sustainable Small-Scale Fisheries: News and Events. 2019. Available online: http://www.fao.org/voluntary-guidelines-small-scale-fisheries/news-and-events/detail/en/ c/1235924/\#: \{\{\}:text=The\%20SSF\%20Guidelines\%20are\%20a, the\%20delivery\%20of\%20different\%20SDGs (accessed on 29 August 2020).

Publisher's Note: MDPI stays neutral with regard to jurisdictional claims in published maps and institutional affiliations.

(C) 2020 by the authors. Licensee MDPI, Basel, Switzerland. This article is an open access article distributed under the terms and conditions of the Creative Commons Attribution (CC BY) license (http://creativecommons.org/licenses/by/4.0/). 